\title{
Deglacial laminated facies on the NW European continental margin: The hydrographic significance of British-Irish Ice Sheet deglaciation and Fleuve Manche paleoriver discharges
}

\author{
F. Eynaud ${ }^{(\mathrm{a})^{\star}}$, S. Zaragosi ${ }^{(\mathrm{a})}$, J.D. Scourse $^{(\mathrm{b})}$, M. Mojtahid $^{(\mathrm{a}, \mathrm{c})}$, J. F. Bourillet $^{(\mathrm{d})}$,
} I. R. Hall ${ }^{(\mathrm{e})}$, A. Penaud ${ }^{(\mathrm{a})}, \mathrm{M}$. Locascio ${ }^{(\mathrm{a})}$, A. Reijonen $^{(\mathrm{a})}$

(a) Université Bordeaux I, UMR 5805 EPOC, Avenue des Facultés, F-33405 Talence, FRANCE

(b) School of Ocean Sciences, University of Wales (Bangor), Menai Bridge, Anglesey, LL59 5AB, UK

(c) now at Laboratory for the Study of Recent and Fossil bio-indicators, CNRS UPRES EA 2644, Angers University, 2 Boulevard Lavoisier, 49045 Angers Cedex, France

(d) IFREMER, Géosciences Marines, Laboratoire Environnements Sédimentaires, BP70, 29280 Plouzané Cedex, France

(e) School of Earth, Ocean and Planetary Sciences, Cardiff University, Park Place, Cardiff CF10 3YE, Wales, U.K.

* corresponding author, email: $\underline{\text { feynaud@epoc.u-bordeaux1.fr }}$

\begin{abstract}
:
We have compiled results obtained from four high sedimentation rate hemipelagic sequences from the Celtic sector of the NW European margin (NE Atlantic) to investigate the paleoceanographic and paleoclimatic evolution of the area over the last few climatic cycles. We focus on periods characteristic of deglacial transitions. We adopt a multiproxy sedimentological, geochemical, and micropaleontological approach, applying a sampling resolution down to ten microns for specific intervals. The investigation demonstrates the relationships between the Bay of Biscay hydrography and the glacial/deglacial history of both the proximal British-Irish Ice Sheet (BIIS) and the western European continent. We identify recurrent phases of laminae deposition concurrent with major BIIS deglacial episodes in all the studied cores. Evidence for abrupt freshwater discharges into the open ocean highlights the influence of such events at a regional scale. We discuss their impact at a global scale considering the present and past key location of the Bay of Biscay versus the Atlantic Meridional Overturning Circulation (AMOC).
\end{abstract}

Keywords: Celtic margin; glacial terminations; laminated sediments; freshwater pulse/discharge; icerafted detritus; planktonic microfossils. 


\section{INTRODUCTION}

It is now commonly accepted that major glacial-interglacial climatic changes are primarily forced by changes in the insolation budget, directly linked to the Earth's orbital parameters (Berger, 1978; Imbrie et al., 1989; Berger and Loutre, 1991). During the Quaternary, boundary conditions between glacial and interglacial stages were repeatedly reached in response to the 100,000 year period of the eccentricity cycle (Imbrie et al., 1993; Shackleton, 2000). The forcing linked to the precession and the obliquity cycles are also registered, the former especially in tropical palaeoenvironments through its influence on monsoon dynamics. Nevertheless, high resolution palaeoclimatic and palaeoceanographic studies, recently supported by modelling experiments, have shown that the orbital forcing may not have been the only control on ice sheet growth and decay (e.g. Shackleton, 2000; Khodry et al., 2001; Crucifix et al., 2001; Charbit et al., 2002). Sub-orbital abrupt events associated with ice sheet calving over the last 40,000 years known as Heinrich events (Heinrich, 1988) clearly illustrate such a phenomenon as their cyclicity does not match any of the classic orbital periodicities (e.g. Bond et al., 1993). Additional evidence similarly comes from the recurrent asynchronism that is observed between major ice-sheet decay and optimum values of June insolation at the top of the atmosphere at $65^{\circ} \mathrm{N}$. This parameter is classically taken by the palaeoclimatic community to represent the solar forcing of changing global climate (Imbrie et al., 1993). Such asynchronism indicates major feedback mechanisms involving the atmosphere, the cryosphere, the oceans and the biosphere, that are far from being completely understood (e.g. Piotrowski et al., 2004; 2005).

Global climate modelling is one of the best tools to investigate these questions: the development of models of intermediate complexity (EMIC) has furnished robust hypotheses to explain global climate sensitivity (e.g. Petoukhov et al., 2005). Nevertheless, ice sheets incorporated in these models are often highly simplified in their dimensions, especially with 
regards to their latitudinal extent. They are classically resolved as massive polar ice caps, following the pattern of those that were developed over large continental areas during glacial maxima (e.g. Smith et al., 2003). Even if the physical processes which drive ice sheet growth and decay are increasingly precisely incorporated into models predicting isostatic rebound and sea-level rise calculation (e.g. Shennan et al., 2000, 2002 for the UK; Spring-AGU 2004 for the Laurentide), until now few simulations (Crucifix et al., 2001) have tested in detail the sensitivity of the response of small-sized and temperate ice sheets to global climate change. Although often small in global terms, the mass balance of these ice sheets is often very sensitive to moisture supply and sea-level change, and they are often situated in critical and sensitive locations with respect to the thermohaline dynamics of the adjacent ocean. This is the case for the British - Irish Ice Sheet (BIIS; MCabe et al., 2005). This temperate ice sheet developed during the Last Glacial Maximum (LGM, Lambeck, 1995; Scourse et al., 2000; Scourse and Furze, 2001; Richter et al., 2001; Bowen et al., 2002; Bourillet et al., 2003; MCabe et al., 2005; Hiemstra et al., 2006) and during earlier glacial periods (Gibbard, 1988; Bowen, 1999; Gibbard and Lautridou, 2003). Based on the identification of a typical sedimentological facies, for which one of the major distinctive features is the deposit of millimetric scale laminations, previous work (Zaragosi et al., 2001a; Mojtahid et al., 2005) has evidenced melting events characteristic of the BIIS / Manche paleoriver purges at the onset of major deglaciation. Until now, these events were documented in the Bay of Biscay on only two cores retrieved in the same area of the Celtic margin (Mojtahid et al., 2005). Here we present data from additional cores retrieved on the Celtic sector of the NW European Margin (from the Porcupine Bight to the Trevelyan Escarpment), all of which showing evidences of the recovery of this typical laminated facies. Integrating these new sequences, the purpose of this paper is to document and discuss the sedimentological and microapaleontological specificity of these events. As potentially representing abrupt BIIS/European deglacial events, 
their impact on the local and regional sea-surface conditions will also be discussed, introducing some elements concerning their possible significance on the Atlantic Meridional Overturning Circulation (AMOC).

\section{2. "THE MANCHE PALEORIVER".}

The study area (Figure 1) is located in the northern part of the Bay of Biscay on the Celtic margin, a margin characterised by two mid-sized deep-sea turbidite systems: the Celtic and Armorican fans (Auffret et al., 2000; Zaragosi et al., 2000; Zaragosi et al., 2001b). These systems were linked to north-western European continental drainage areas via the "Manche palaeoriver" during low-stands of eustatic sea level (Bourillet et al., 2003). This fluvial system extended from the southern North Sea to the Bay of Biscay. It included the English Channel, a portion of the continental shelf, the slope where the canyons network split around two structural hights, the Trevelyan escarpment (TE) and its adjoining Meriadzek terrace (MT), feeding down slope the Celtic and Armorican fans (Bourillet et al., 2006). The TE and MT stand at least 600 meters above the adjacent abyssal plain (Figure 1). During the most recent glacial stages of the Quaternary, the Manche palaeoriver flowed westwards from the southern North Sea along the centre of the English Channel (Lericolais, 1997, Lericolais et al., 2003). This palaeoriver was supplied via the connected drainage basins of modern rivers including the Seine, the Somme, the Solent and probably the Meuse, the Rhine and the Thames (Larsonneur et al., 1982; Gibbard, 1988; Lericolais, 1997). It fed via the palaeovalley (Lericolais, 1997) and the delta of the palaeoriver (Bourillet et al., 2006) into some of the canyons of the slope (Bourillet and Lericolais, 2003) converging at the edge of the continental shelf (200 m) and extending into the deep ocean (4500 m). Sediment fluxes into the deep ocean were directly influenced by the growth and decay of the adjacent BIIS, both via the 
Manche palaeoriver and the Irish Sea Basin (e.g. McCabe and Clark, 1998; Richter et al., 2001; Bowen et al., 2002; McCabe et al., 2005).

\section{MATERIALS AND METHODS}

Several cruises onboard the oceanographic research vessels "Marion Dufresne II" (IPEV) and Atalante (Ifremer) have been undertaken on the margin during the last 10 years (IMAGES 1, SEDIMANCHE, ZEE-GASC, SEDIFAN, GINNA, GEOSCIENCES, SEDICAR), allowing the discovery of particular sites and the subsequent recovery of high sedimentation rate sequences. Cores MD95-2001 and MD95-2002 located respectively on the TE and the MT (Table1; Figure 1), complemented by core AKS01 (SHOM cruise, 1996) retrieved at the western boundary of the TE, reveal a detailed record of the last 25 ka with a regionally coherent deglacial scheme strongly influenced by the BIIS history (Grousset et al., 2000; Zaragosi et al., 2001a). These records have been recently complemented by cores MD01-2461 and MD03-2692, retrieved from the western Porcupine Bight and Trevelyan Escarpment respectively. These cores, of which the longest extends to $360 \mathrm{ka}$, have provided access to older terminations: i.e. Terminations 2, 3 and 4.

Following the work described in Zaragosi et al. (2001a), a multidisciplinary approach has been applied to the study the four cited MD cores, using physical, stratigraphical, geochemical, sedimentological and micropaleontological tools.

The microstructure of the sediment were investigated using X-ray imagery, using the SCOPIX image-processing tool (Migeon et al., 1999). For part of the core containing laminae, this was coupled to microscopic photography on impregnated sediment sections (image acquisition consisted of a fully automated Leica DM6000 Digital Microscope with multiple magnifications giving access to a $10 \mu \mathrm{m}$ resolution; see the detailed method in Zaragosi et al., 2006). This was complemented by individual granulometric analyses (Malvern Mastersizer S) 
of the laminae with a delicate sub-sampling of the X-Ray dark versus the X-Ray bright laminae for which automatical counts of lithics $>150 \mu \mathrm{m}$ were also made.

Known aliquots of the dried residues $(>150 \mu m)$ were counted for their planktonic foraminiferal content to obtain relative abundances (percentages) of Neogloboquadrina pachyderma sinistral versus the total planktonic fauna. The coarse lithic grains (CLG) were characterized and counted on the same fraction $(>150 \mu \mathrm{m})$ and include Ice Rafted Detritus (IRD) which indicate iceberg melt fluxes. The data were then expressed in concentration: number of grains per gram of dry sediment. Palynomorph analysis was performed using the $<150 \mu \mathrm{m}$ fraction. Counting included quaternary and non-quaternary (reworked) dinocysts and fresh-water alga Pediastrum sp.. The ratio calculated on the basis of reworked versus modern dinocysts $\left[\mathrm{R}_{d} / \mathrm{M}_{\mathrm{d}}\right]$ is here interpreted as an index of allochtonous sedimentary supplies (Zaragosi et al., 2001a). Identification of reworked dinocysts shows that they are derived from mixed sources of Jurassic, Cretaceous and Palaeogene chalk, marl and limestone (Kaiser, 2001). This information does not really allow us to constrain the sediment source area as these geological formations can be localized both in the Irish Sea, the south of UK, the north of Belgium, the Paris basin and the Manche substratum itself.

The age models of the studied cores have been established on the basis of AMS ${ }^{14} \mathrm{C}$ dates between 0 and 30 ka for MD95-2002 (Figure 2, Table 2; $11{ }^{14} \mathrm{C}$ dates, Zaragosi et al., 2006), MD01-2461 (13 ${ }^{14} \mathrm{C}$ dates for the last deglaciation, see Peck et al., 2006) and MD03-2692 (Table 2; $16{ }^{14} \mathrm{C}$ dates, this study). Radiocarbon ages were calibrated to calendar years before present (yr BP) using the CALIB programme (version 5.1.0 with the MARINE04 data set, incorporating a $400 \mathrm{yr}$ correction for marine reservoir; same methods and correction as those used in Menot et al., 2006). Oldest ages were converted using Bard (1998). Ages between the stratigraphic references have been calculated by polynomial regression - $\mathrm{d}^{\circ} 5$ for MD95-2002 
and MD03-2692 (cores used in this paper as references for the area; Figure 2). A polynomial fit was calculated separately for the ${ }^{14} \mathrm{C}$ ages and for the calibrated ages. Calibrated ages in Table 2 are based on the original dates and not on ${ }^{14} \mathrm{C}$ ages derived for the respective depth from the polynomial fit. Beyond the range of AMS ${ }^{14} \mathrm{C}$ ages, the stratigraphy has been complemented by stable isotope and carbonate content measurements. Benthic and planktonic $\delta^{18} \mathrm{O}$ records reveal climatic oscillations that can be used to constrain the age models by a direct comparison with the SPECMAP $\delta^{18} \mathrm{O}$ curve (Martinson et al., 1987). The software used for this peak to peak correlation was the "AnalySeries" software (Paillard et al., 1993; the detailed method is explained in Mojtahid et al., 2005). Stable isotope carbonate, and light reflectance records obtained also on the closely related sequences AKS01 and MD95-2001 were used to tied their stratigraphy to a regional scale.

\section{RESULTS AND DISCUSSION}

\subsection{What is characteristic of the laminated sequences of the Celtic margin?}

The studied sequences all consist of hemipelagic clays. On the basis of X-ray imagery, we have recognized typical sedimentary fabrics and facies, i.e. laminated sediments, that previous works have genetically and principally linked to increased runoff of the Manche palaeoriver both due to deglacial melting of the BIIS and of alpine glaciers (Zaragosi et al., 2001a; Mojtahid et al., 2005). In this paper, we show that these laminated sequences occur in almost all the studied cores from the northernmost $\left(51.7^{\circ} \mathrm{N}\right)$ to the southermost site $\left(46.8^{\circ} \mathrm{N}\right)$ of the investigated area (Figure 1), therefore potentially enlarging the BIIS/European deglacial melting plume influence on the Celtic Margin. Figure 3 identifies their intervals within the respective records. They are presented in depth in the cores to underline the regional similarity of their thickness, that extends from $100 \mathrm{~cm}$ for the thinner (core MD95-2001, MIS 6) to $270 \mathrm{~cm}$ for the thickest record (core MD95-2002, MIS 2). These laminated deposits are 
distinguished from the rest of the hemipelagic background sedimentation on the basis of the following criteria (Figures 4 et 5):

(1) The laminae intervals consist of a succession of strictly horizontal and parallel X-ray dark and bright laminations (Figure 4). All the laminae present a main granulometric mode at $4 \mu \mathrm{m}$ confirming that they are primarily composed of clays. Granulometric curves of the dark laminae present slightly higher values in the silt and sand fractions (black curves on Figure 4). Observations of the sediment slides (Figure 4) show that the coarse fraction is characterized by sub-angular silts and sands floating in a clayey matrix. This suggests that all the laminae are composed by the same clayey material but with the addition of coarse grained clasts for the X-ray dark laminae. The absence of cross bedding, graded bedding and the mainly clayey composition of all the laminae exclude a contouritic or turbiditic origin for the laminae. These coarse-grained clasts therefore probably originated from the deposition of icerafted debris. According to sedimentation rates of about $0.5 \mathrm{~cm} / \mathrm{yr}$, the thin section in Fig 4a (core MD03-2692) represents about 20 years of sedimentation; 16 ice-rafted laminae are found within this interval.

(2) Concentrations of coarse lithic grains (CLG, including ice-rafted detritus -IRD) are low in the studied cores, excepted during deglacial events: i.e. Heinrich Events (HEs, Heinrich 1988; Grousset et al., 2000; Zaragosi et al., 2001a; Auffret et al., 2002; Mojtahid et al., 2005; Peck et al., 2006). With regards to the laminae deposits, these CLG concentrations reach values in between 200 to 500 grains./g dry sed. (Figure 5). The laminae are often marked by abrupt changes in the CLG concentrations. No clear temporal succession is observed for the deposits of MIS6, in contrast to MIS 2 where the laminae sequence records a typical multi- step structure associated with Termination 1 (Figure 5a and 5b).

The HE1 boundary we used conforms to the age limits published by Elliot et al. $(1998,2001)$ and those used in Zaragosi et al. (2001a). According to our records, HE1 first occurrence of 
CLG at 18.2 ka cal-BP (15 ka- ${ }^{14} \mathrm{CBP}$ ) synchronously corresponds to first evidence of $N$. pachyderma monospecific values and to the onset of laminae deposits. Concentrations of CLG then increase from 0 to a mean of 300 grains./g dry sed., a concentration that remains constant during the laminae event. It is later followed by an abrupt increase by a factor 4 to 5 of CLG concentrations (up to 2000 grains./g dry sed.), that corresponds to the massive Canadian discharge (Grousset et al., 2000; Zaragosi et al., 2001a; Auffret et al., 2002; Menot et al., 2006). It has been attributed to a two-step regional record within HE1, first with diluted IRD concentrations, that indicate iceberg calving but also high freshwater and sedimentary fluxes from proximal sources in response to ice jump and snow melt flood (fluvial-sourced via the Manche palaeoriver in connection to major European rivers, including those linked to the French Alps; Zaragosi et al., 2001a; Menot et al., 2006; Van Vliet-Lanoë, pers. com.). Indeed sedimentation rates reach $400 \mathrm{~cm} . \mathrm{ka}^{-1}$ in core MD95-2002. This event is then followed by the major calving of pan-Atlantic ice sheets (Figure 6; Zaragosi et al., 2001a; Auffret et al., 2002; Mojtahid et al., 2005), documented as early as 17.5 ka cal BP in the North Atlantic by a cessation of the AMOC (McManus et al., 2004). Interestingly, this change in IRD concentrations and sedimentary fluxes (Figure 6) occurs synchronously from a BIIS extensive deglaciation (Bowen et al., 2002). At $16.7 \mathrm{ka}$ cal BP (14 ka ${ }^{14} \mathrm{C}$ BP), a short icesheet readvance known as the Killard Point stadial (McCabe et al., 2005) is noted on land in northern Britain but also in the north Irish Sea basin. This was followed by a rapid ice recession after $16.4 \mathrm{ka}$ cal $\mathrm{BP}\left(13.8 \mathrm{ka}{ }^{14} \mathrm{C} \mathrm{BP}\right)$.

(3) Other analysed proxies (micropalaeontological tools) complement the characterization of sea-surface conditions linked to the laminae deposits. The deposits show quasimonospecifism of the polar foraminiferal species $N$. pachyderma sinistral. It indicates cold sea-surface temperatures (SST), with a mean annual SST of $<5^{\circ} \mathrm{C}$. This could be linked to either migration of the Polar Front or the local establishment of cold superficial conditions. 
Evidence for such cold environments suggests a zonal change in the water mass distribution. This change was particularly marked by the contrasting conditions prevailing prior to the onset of laminae deposition which, as demonstrated by low values in $N$. pachyderma s. percentages, must correspond to warm SST (Figure 5a and 5b).

With the study of palynomorphs from the $<150 \mu$ m fraction, we also observed major changes in the composition of the phytoplanktonic microflora (Figure 5). The most pronounced feature is a marked increase in the relative abundances of the estuarine dinocyst $L$. machaerophorum, synchronous with an increase in the flux of non-Quaternary reworked palynomorphs and freshwater algae (Pediastrum sp.). It was recurrently observed for the laminae section of both MIS2 and MIS6, suggesting surficial water-masses invaded by large freshwater plumes.

Together these observations are coherent to indicate large freshwater injection events in the northern Bay of Biscay. We named them Celtic-freshwater pulses (Celtic-FWP). This work shows, for the first time, that these events could have extended on a radius as long as $500 \mathrm{~km}$ away from their main source area, i.e. the mouth of Manche palaeoriver, probably at this time joined by a contributor through the Irish sea (McCabe et al., 2005; Hiemstra et al., 2006). Material included in the laminae was derived from large decay both linked to riverine and meltwater sources (Zaragosi et al., 2001a, 2006; Menot et al., 2006).

Concerning the recurrence of these events, a remaining question is the absence of laminae in core MD01-2461 during Termination 1 (Peck et al., 2006) while they are well preserved during the MIS6 laminae event (Figure 2). It should also be noted that this facies was also absent within the OMEX cores from the deeper parts of the Goban Spur (Figure 1, Hall and McCave, 1998a and b). This dissimilarity occurring inbetween the two time periods could be explained by a different routing of meltwaters (Knight and McCabe, 1997; McCabe et al., 
1998; McCabe et al., 2005). For the last deglaciation, the melting of the Irish Ice-Sheet was mainly routed via the Irish Sea towards the Bay of Biscay as demonstrated with the mapping of an Irish Sea Basin paleo-ice stream (Stockes et Clark, 2001; Richter et al., 2001; McCabe et al., 2005; Hiemstra et al., 2006). Maybe this routing did not allow the deposit to occur as far north as the Porcupine bight. This could also be due to differences in the Fennoscandian melting ice edge which could have been closer to the study area (case of MIS6, Svendsen et al., 2004) and could potentially have led to a higher freshwater run-off that induced laminae formation even in the Porcupine Bight. Further cores are clearly needed in order to address this issue.

\subsection{The laminae: an imprint of the BIIS seasonal decay?}

The duration of the FWP events is a key question that relates to the question of laminae frequency: do the laminae constitute a multi-annual, annual, or even a seasonal signal? It is important that this is interpreted in the light of the radiometric data. We therefore focus our discussion on the laminae event of "early Termination $1 "$. This event is recorded in the cores MD95-2001, MD95-2002 and MD03-2692 (Figure 1, Figure 3). We previously interpreted it as the record of annual changes in sedimentation (Mojtahid et al., 2005; Zaragosi et al., 2006). This interpretation was supported by the glacial context of the region at this time involving large IRD flux into the Bay of Biscay from seasonal decay during the spring. Such a model was first presented in Mojtahid et al. (2005) based on a comparison with the results obtained during HEs in the Labrador Sea (Hesse and Khodabakhsh, 1998). For the present work, six AMS radiocarbon dates were obtained within the laminated sequence in core MD03-2692 to address the critical issue of its exact duration (Figure 6). These ${ }^{14} \mathrm{C}$ dates indicate that the laminated sequence accumulated over an interval of 700 years (1000 years cal BP at this period). Previous work on core MD95-2002 (Zaragosi et al., 2001a) constrained the duration 
of this event to $800 \pm 100$ years (14C) based on two dates over the laminated interval. However, these duration could be questioned regarding the reservoir ages in this period of intensified freshwater release and probable ventilation inhibition (Waelbroeck et al., 2001; Björck et al., 2003; Peck et al., 2006). Accordingly the dates we obtained potentially over- or under-estimate the duration of the laminae event. To solve this question, other dating methods need to be investigated (e.g. optically stimulated luminescence dating, work in progress). This would also be improved by an accurate micro-sampling of the laminae.

Apart from these methodological problems, however, the laminae duration could be compared to results of recent modelling exercises that show that HEs were abrupt and violent events (Ganopolski and Rahmstorf, 2001; Roche et al., 2004). For example, for HE4, one of the most extreme HEs recorded in the North Atlantic (Cortijo et al., 1997), the duration of the freshwater release was calculated as representing a perturbation of $250 \pm 150$ years (Roche et al., 2004). This is quite short compared to our estimation for the HE1 laminae event, that constitute furthermore only the first part of the injection of freshwater in the system (early part of HE1 only). Conversely, a duration of 700 years is compatible with the data presented by Hemming (2004), who gives a range for the duration of HE1 of between 208 and 1410 years.

The highest concentration of laminae, with at least two laminae per $\mathrm{cm}$, is recorded at the beginning of the event. During this interval, sedimentation rates were in excess of $500 \mathrm{~cm} / \mathrm{ka}$, equivalent to 0.5 to $1 \mathrm{~cm}$ per year. This high accumulation rate implies that the laminae are likely to be annual or semi-annual in nature and supports the seasonal hypothesis presented in Mojtahid et al. (2005). Based on the assumption of an annual signal, individual counting of laminae in MD03-2692 give an age of 91 years for the duration of the event. This must, however, represent a minimum estimate, as fine laminae might have been missed and also 
because continuous laminae deposition through time is rare, even in lakes (Tian et al., 2005), and should therefore not be expected in the deep-sea environment of the Bay of Biscay.

\subsection{The laminae : are they recurrent phenomenon marking the onset of Termination?}

As previously shown on Figure 3, laminae events were also recorded during the late Marine isotope stage (MIS) 6. They were observed on the 3 cores extending beyond MIS5, therefore representing a latitudinal expansion as large as for the MIS2 event. The stratigraphical position of these laminae events was determined on the basis of a correlation between the SPECMAP curve (Martinson et al., 1987) and our benthic $\delta^{18} \mathrm{O}$ records, as explained in Section 3. In the core MD01-2461, the dating of a perfectly preserved coral found at $1560 \mathrm{~cm}$ by U-TH methods (GEOTOP, http://www.geotop.uqam.ca/) has given a date of 139.77 ka BP \pm 2500 years (Claude Hillaire-Marcel and Bassam Ghaled, pers. com.). This solitary coral was localized more than $200 \mathrm{~cm}$ above the last occurrence of laminae, implying therefore that their deposit occurred prior to Termination 2. This result corroborates Mojtahid et al. (2005), who have dated this Celtic-FWP between 150 and 145 ka BP. This event hence represents an early event of melting that leads the onset of northern hemisphere deglaciation (Figure 7). The existence of this delay brings to mind a long standing debate concerning the chronology of Termination 2, that was initiated by the datation of a speleothem (Devils Hole, US) by Winograd et al. (1992, 1997). The speleothem position at stage 6/5e transition at Devils hole at $144 \mathrm{yr} \mathrm{BP}$ suggests that the penultimate deglaciation may have begun earlier that the SPECMAP marine isotope curve reveals. It was later supported by ${ }^{230} \mathrm{Th}$ and ${ }^{231} \mathrm{~Pa}$ dating of coral terraces (Galup et al., 2002). On the other hand, stacked benthic $\delta^{18} \mathrm{O}$ curves including SPECMAP (e.g. Imbrie et al., 1984, Martinson et al., 1987; Raymo, 1997; Waelbroeck et al. 2002) depict a double step process for the penultimate deglaciation, with a first deglacial 
pulse dated between 150 and 145 ka (6.3 event, if we follow the recent and robust chronology of Waelbroeck et al., 2002) that perfectly fits with the Celtic -FWP.

Climate warming preceding high latitude ice sheet retreat at Termination 2 has been reported from other records worldwide. In the north Atlantic, the Celtic-FWP event is contemporaneous with a warming recorded in the tropics (Schneider et al., 1999). This warming is registered in UK-37 SST, in phase with an eccentricity minima but it shows a lag of 20 ka with the benthic $\delta^{18} \mathrm{O}$ record. Such an early warming has also been suggested by Lea et al. (2002), with the onset of the warming at around $150 \mathrm{ka} \mathrm{BP.} \mathrm{The} \mathrm{cited} \mathrm{records} \mathrm{are} \mathrm{from}$ mid- to low latitudes implying that the warming during the glacial-interglacial transition occurred first at low latitudes. No pertinent records exist in closer area of the Celtic margin to depict this early warming in Europe (neither speleothems, nor pollen records with the requested resolution and stratigraphic accuracy for this time slice). Some confusions could occur considering the Zeifen interstadial but several studies dated its occurrence later within the Termination 2 (after 140 ka, Seidenkrantz et al., 1996; Sanchez-Goni et al., 1999).

Interestingly, the age of 150 ka corresponds in the northern hemisphere insolation curve to a decoupling between the $15^{\circ} \mathrm{N}$ and $65^{\circ} \mathrm{N}$ July insolation values, with a maxima for tropical insolation larger than $25 \mathrm{Watt} / \mathrm{m}^{2}$ comparing to the maxima that occurs at the same time in high latitudes (Figure 7). Such a feature is unique but seems recurrent prior to every termination. This decoupling could argue for early response of the temperate BIIS, asynchronously from boreal ice-sheets. It may therefore imply that the BIIS decay is first forced by low latitude climatic changes. If confirmed, this result underlines its sensitivity and maybe a precursive reaction to climate change. It is also coherent with models that show that deglaciation is primarily driven by insolation (Charbit et al., 2005). 
Our results reinforce the question about the age and duration to consider for the Ultimate Glacial Maximum (ULM) in MIS6, as still debated for the orbital theory of ice ages (see Cannariato and Kennett, 2005).

The discussion of the occurrence of laminae for the older terminations is limited by the fact that to date, only the MD03-2692 core preserves a record for these periods. In this core, no laminations were associated for either Termination 3 nor Termination 4 (as far as our record allows us to document the last millennia of MIS10). For Termination 3, Motjahid et al. (2005) interpreted this as related to the size of the BIIS. It is consistent with the trend observed in the late Quaternary based on benthic oxygen isotope records (e.g. Shackleton et al., 1988, Waelbroeck et al. 2002; Siddal et al., 2003) which show a reduced mid-amplitude of Northern Hemisphere glaciation during MIS8. If BIIS development was then limited at that time, deglacial supplies may not have been large enough to allow laminae deposition. If pertinent, this observation could definitively argue for a genetic link between laminae and maximal BIIS development. No deposition could also be inferred from changes in the extend of the Scandinavian Ice Sheet into middle Europe and in the routing for the meltwater run-off. At least during MIS 6, the Scandinavian Ice Sheet advanced much further south into Germany and the Netherlands (Svendsen et al., 2004) hence its melting ice edge would have been closer to the study area and could potentially have led to a higher freshwater run-off that induced laminae formation. However, precise palaeogeographic informations are lacking to interpret correctly MIS 8 ice-sheet extension and its potential meltwater routing (Mangerud et al., 1996).

4.4. Could the melting have introduced a perturbation in the AMOC system? Ideas and controversial points 
The last deglaciation period is the only one that allows a discussion on processes and feedback mechanisms characteristic of deglacial transitions thanks to a robust chronological framework. The following discussion will thus be focussed on the MIS 2 Celtic-freshwater pulse (Celtic-FWP). We will analyse the temporal sequencing of events (Figure 6) to address the significance of the Celtic-FWP to regional or even global climate.

During the early deglaciation, the first deposit of laminae is dated around $18 \mathrm{ka}$ cal BP, contemporaneous with the beginning of HE1 in the open Atlantic (Elliot et al., 2001) and an induced collapse of the AMOC (Mc Manus et al., 2004, Hall et al., 2006). This laminae deposit ended at 17 ka cal BP, followed by the most intense phase of HE1 (sensu Heinrich, 1988). The Laurentide Ice-Sheet (LIS) HE1 event, identified on the NW European margin cores by high magnetic susceptibility values (Zaragosi et al., 2001a; Auffret et al., 2002), is recorded later in our core with CLG concentrations approaching 2000 grains $/ \mathrm{cm}^{3}$. This two step structure, also previously identified on this margin (Grousset et al., 2001; Zaragosi et al., 2001a; Auffret et al., 2002; Knutz et al., 2001; Peck et al., 2006; Hall et al., 2006) and in the Norwegian Sea (Lekens et al., 2005) and off Portugal (Schönfeld et al., 2003) suggests a regionally consistent signature for HE1 on the NW European margin.

The phasing between the Celtic-FWP event and then the BIIS decay with the major glacial discharges of the Laurentide and Fennoscandian ice sheets during HE1 might imply a causal relationship between the two events. There are at least two possible candidate mechanisms: (i) a sea-level change and (ii) a disruption of the thermohaline circulation. We discuss them below :

(i) The BIIS at the LGM, which was approximately twice its ice volume during HE1, only contributes to a global glacio-eustatic lowering of $0.91 \mathrm{~m}$ (Boulton et al., 1977), some 0.76\% of the global ice volume difference between the LGM and the present day (Scourse, 1997). Thus, even if the entire BIIS had collapsed during the early part of HE1, which we know was 
not the case from terrestrial evidence (Mc Cabe et al., 2005), sea level would only have risen by less than $0.5 \mathrm{~m}$. The actual figure may be estimated at being closer to $0.1 \mathrm{~m}$. This value lies within the tidal range of the region at this time (Uehara et al., submitted) and could easily be generated by a small storm surge. It is unlikely to cause widespread destabilisation of panAtlantic ice sheets and shelves.

(ii) The second mechanism is, to some extent, supported by our data. We provide evidence for the establishment of polar conditions in the Bay of Biscay coeval with freshwater arrivals and the deposition of the laminae. Prior to that, the Last Glacial Maximum (LGM sensu Mix et al., 2001) was punctuated by several warm events in this region (Zaragosi et al., 2001a; Mojtahid et al., 2005) with palynological data suggesting active penetration of the North Atlantic Drift (NAD) across the Celtic margin (Eynaud, 1999). The warmth associated with this current would have been inhibited as soon as freshwater/meltwater injection began. This is evidenced south of the BIIS by our data, but also in northwestern environments by meltwater injections into the Rockall Trough (Richter et al., 2001; Knutz et al., 2001; Clark et al., 2004). In these areas, the BIIS has been a potential source of continuous iceberg releases (Knutz et al., 2007). Given the significance of freshwater flux in controlling the stability of AMOC in the North Atlantic (e.g. Broecker et al., 1990; Mc Manus et al., 2004; Hall et al., 2006), it could be possible, as also suggested by Clark et al. (2004), that it has had direct impact on the NAD, maybe partially deviating it far off the British Isles. It could thus have possibly resulted in a perturbation of the subpolar gyre with consequences on the Irminger Current (IC, Blindheim et al., 2000; Figure 1). A change in the heat flux associated with this major component of the thermohaline circulation (THC) could have had a very sensitive effect on the Nordic seas (especially in the Iceland-Faeroe-Shetland major sill area) and therefore on the surrounding continents. This scenario presently lacks a modelling exercise, but very few coupled models possess the required sensitivity and gridding as small as is needed for the modelling of the 
Celtic-FWP and its impact on the North Atlantic. However, we can tentatively draw down a conceptual scenario based on the existing literature concerning the AMOC.

Perturbations of the AMOC have been intensively modelled during the last decade (hysteresis response, e.g. Stocker et al., 1997; Rahmstorf, 1999; Wood et al., 1999; Paillard, 2001; Seidov and Haupt, 2003; Roche et al., 2004) demonstrating the significance of thresholds within the climate system. In a recent paper, Charbit et al. (2005) demonstrated that, for the last deglaciation, the melting of the North American ice sheet was critically dependent on the deglaciation of Fennoscandia through processes involving switches of the thermohaline circulation from a glacial mode to a modern one and associated warming of the northern hemisphere. Both the surface and deep structure of the THC could be affected by only a minor change in the saline budget (freshwater runoff and precipitations) of the Nordic seas if freshwater is injected into convectively sensitive locales (see Clark et al., 2002).

More than the volume implied in these mechanisms, is the geographic location of the freshwater injection of major significance. Actually, evidence on BIIS thickness and extent, and therefore volume, suggest that in sverdrup-equivalent units it was not sufficiently large enough to disrupt the THC (Scourse, 1997; Shennan et al., 2002; Clark et al., 2004; Evans et al., 2005). At the opposite, the western peri-BIIS hydrographic setting is presently very sensible regarding thermohaline circulation, as it includes two major components: the NAD and the Mediterranean Overflow Waters (MOW), upwelled off Ireland at 53N (Porcupine Bank; Van Akken, 2000). This junction has been named the "Mediterranean salinity valve" as the MOW increases the salt budget of the NAD and contributes to the warm inflow to the Nordic Seas (McCartney and Mauritzen, 2001). It has been recognized as a major actor of the AMOC, especially during glacial-interglacial climate changes, but also during short-term climatic changes (Johnson, 1997; Cacho et al., 2000; Schönfeld and Zahn, 2000; Voelker et al., 2006; Dorschel et al., 2006). 
455

456

457

458

459

460

461

462

463

464

What kind of scenario then could be drawn under glacial conditions? The major topographic control of MOW flow suggests a significant reorganisation of this system from the Gibraltar Strait to the Porcupine Bight (Dorschel et al., 2006). Apart from periods of extreme low stand of sea-level, the MOW contribution to the AMOC was efficient, and then possibly strengthened during HEs (Voelker et al., 2006). However, with surface freshwater injections in close area of the MOW upwelling, could we envisage that the salt adjunction of the MOW was still efficient? Does it question the balance between the cyclonic flow of the NAD along the Norwegian coast and its anticyclonic branch, the IC? According to Johnson (1997), strengthening of the IC results in warming of the Labrador Sea that enhances precipitation over Northern Canada, finally driving the growth of the Laurentide Ice Sheet. Conversely, following Hulbe et al. (2004), this warming could have initiated the disintegration of iceshelves surrounding the Labrador Sea, thus initiating a HE.

However a controversial point consists in how the MOW impacts on AMOC: under "the deep source" hypothesis, inflow waters to the Nordic Seas originate from the core of the MOW in the Gulf of Cadiz carried northward at mid-depth by the eastern boundary undercurrent in the subtropics, continuing into the subpolar gyre along the eastern boundary, and rising from depths near $1200 \mathrm{~m}$ in the Rockall Trough to less than $600 \mathrm{~m}$ to cross the Wyville-Thomson Ridge into the Faroe-Shetland Channel and thence the Nordic Seas (McCartney and Mauritzen, 2001). Following McCartney and Mauritzen (2001), this deep source hypothesis is however not fully supported by data. Accordingly, the MOW forcing would be better defined in its temperature-salinity relationship of the interior of the subtropical gyre from which the NAD draws its water, rather than by direct northward advection. If verified, this last option definitively closes our questioning regarding the impact of the Celtic-MWP on AMOC via derived MOW perturbation. 


\section{CONCLUSIONS}

A regionally recurrent pattern of sedimentation characteristic of deglacial transitions has been identified on the Celtic margin, characterised by: (i) freezing sea-surface conditions with evidence for freshwater discharges and IRD deposition; (ii) laminae deposits possibly representing seasonal signals. On the basis of a compilation of multicore and multiproxy data, we interpret these facies as representing deglacial signal of the adjacent BIIS with a possible contribution from the Alps routed via the Rhine river and the Manche palaeoriver. It is likely that the injection of this freshwater and the iceberg release into the climatically-sensitive NE Atlantic have perturbed regional hydrography. This naturally brings stimulating, but hard to solve questions about its impact on the AMOC. This impact could have been emphasized by the short duration of the event, possibly shorter than 100 years (based on laminae counts). Interestingly, dates obtained on the younger part of the studied cores reveal a synchronism of the Celtic-FWP with the beginning of HE1 and subsequently the last deglaciation in the open Atlantic. On the other way, this phasing is not recorded for the penultimate deglaciation, suggesting a decoupling of the BIIS response with the larger boreal ice-sheets and then possibly a tropical control of BIIS decay mechanisms at this time. It addresses questions about the similarity and structures of the terminations throughout time, and consequently about the orbital ice-age theory.

\section{ACKNOWLEDGMENTS:}

The authors are grateful to IPEV, the captain and the crew of the Marion Dufresne and the scientific team of the SEDICAR cruise carried out within the framework of URM17 unit. We wish to thank Mr. Y. Balut for his assistance at sea. M-H. Castera, G. Chabaud, K. Charlier, 
D. P. Kennedy, B. Martin, J. St Paul and O. Ther provided invaluable technical assistance. Thanks are due to A. Pietrowski -Furze for her comments. We thank Bassam Ghaleb and Claude Hillaire-Marcel from the GEOTOP (Montréal, Canada) for the U/Th measurements made on the coral. Comments of two anonymous reviewers significantly benefited this paper. We acknowledge financial support by the ARTEMIS ${ }^{14} \mathrm{C}$ Accelerator Mass Spectrometry French project, but also from the ANR "IDEGLACE". Part of the analyses conducted on MD03-2692 were supported by the SHOM. This is U.M.R./EPOC 5805 (Université Bordeaux I-C.N.R.S.) contribution No 1660.

\section{REFERENCES}

Auffret, G., Zaragosi, S., Voisset, M., Droz, L., Loubrieu, B., Pelleau, P., Savoye, B., Bourillet, J.-F., Baltzer, A., Bourquin, S., Dennielou, B., Coutelle, A., Weber, N. and G. Floch (2000), First observations on the morphology and recent sedimentary processes of the Celtic Deep Sea Fan, Oceanologica Acta 23, 109-116.

Auffret, G., Zaragosi, S., Dennielou, B., Cortijo, E., Van Rooij, D., Grousset, F., Pujol, C., Eynaud, F., and M. Siegert (2002), Terrigenous fluxes at the Celtic margin during the last glacial cycle, Marine Geology, 188, 79-108.

Bard, E. (1998), Geochemical and geophysical implications of the radiocarbon calibration, Geochimica Cosmochimica Acta 62, 2025 -2038.

Berger, A. L. (1978), Long-term variations of daily insolation and Quaternary climatic change, Journal of Atmospheric Sciences, 35, 2362-2367.

Berger, A., and M. F. Loutre (1991), Insolation values for the climate of the last 10 millions years, Quaternary Science review, 10, 297-317.

Björck, S., Koç, N., and G. Skog (2003), Consistently large marine reservoir ages in the Norwegian Sea during the Last Deglaciation, Quaternary Science Reviews, 22, 429-435. 
Blindheim, J., V. Borokov, B. Hansen, S.A. Malmberg, W.R. Turrell, and S. Osterhus (2000), Upper layer cooling and freshening in the Norwegian Sea in relation to atmospheric forcing, Deep-Sea Research Part I, 47, 655-680.

Bond, G., Broecker, W., Johnsen, S., McManus, J., Labeyrie, L., Jouzel, G., and G. Bonani (1993), Correlations between climate records from North Atlantic sediments and Greenland ice, Nature, 365, 143-147.

Boulton, G. S., Jones, A. S., Clayton, K. M., and M.J. Kenning, (1977), A British ice-sheet model and patterns of glacial erosion and deposition in Britain. In British Quaternary Studies, edited by F.W. Shotton,. pp.231-246, Claren don Press, Oxford.

Bourillet, J.-F., and J.-L. Turon (2003), Rapport scientifique de la mission MD133/SEDICAR. OCE/2003/04, Les rapports de campagne à la mer, IPEV, 150 pp., Brest.

Bourillet, J. F., and G. Lericolais (2003), Morphology and seismic stratigraphy of the Manche paleoriver system, Western Approaches margin. In European Margin Sediment Dynamics: Side -Scan Sonar and Seismic Images, edited by J. Mienert and P. P. Weaver, pp. 229-232, Springer, Berlin.

Bourillet, J. F, Reynaud, J. Y., Baltzer, A., and S. Zaragosi (2003), The "Fleuve Manche”: the sub-marine sedimentary features from the outer shelf to the deep-sea fans, Journal of Quaternary Science, 18, 261-282.

Bourillet J-F., Zaragosi S and T. Mulder (2006), The French Atlantic margin and the deep sea submarine systems, Geo-Marine Letters, 26 (6), 311-315.

Bowen, D.Q., Phillips, F.M., McCabe, A.M., Knutz, P.C., and G.A. Sykes (2002), New data for the Last Glacial Maximum in Great Britain and Ireland, Quaternary Science Reviews, 21, 89-101. 
Broecker, W. S., Bond, G., and M. Klas (1990), A salt oscillator in the glacial Atlantic? 1. The concept, Paleoceanography 5 (4), 469-477.

Cacho, I., Grimalt, J. O., Sierro, J. F., Shackleton, N., and M. Canals (2000), Evidence for enhanced Mediterranean thermohaline circulation during rapid climatic coolings, Earth and Planetary Science Letters, 183, 417-429.

Cannariato, K. G., and J. P. Kennett (2005), Structure of the penultimate deglaication along the California margin and implications for Milankovitch theory, Geology, 33, 157-160.

Charbit, S., Ritz, C., and G. Ramstein, (2002), Simulations of Northern Hemisphere ice-sheet retreat: sensitivity to physical mechanisms involved during the Last Deglaciation, Quaternary Science Reviews, 21, 243-265.

Charbit, S., Kageyama, M., Roche, D., Ritz, C., and G. Ramstein (2005), Investigating the mechanisms leading to the deglaciation of past continental northern hemisphere ice sheets with the CLIMBER-GREMLINS coupled model, Global and Planetary Change, 48, 253273.

Clark, P. U., Pisias, N. G., Stocker, T. F., and A. Weaver (2002), The role of the thermohaline circulation in abrupt climate change, Nature, 415, 863-869.

Clark, P. U., McCabe, A. M., Mix, A. C., and A. J. Weaver (2004), Rapid rise of sea level 19,000 years ago and its global implications, Science, 304, 1141-1144.

Cortijo, E., Labeyrie, L., Vidal, L., Vautravers, M., Chapman, M., Duplessy, J. C., Elliot, M., Arnold, M., Turon, J. L. and G.A. Auffret (1997), Changes in sea surface hydrology associated with Heinrich event 4 in the North Atlantic Ocean between $40^{\circ}$ and $60^{\circ} \mathrm{N}$, Earth and Planetary Science Letters, 146, 29-45.

Crucifix, M., Loutre, M.-F., Lambeck, K., and A. Berger (2001), Effect of isostatic rebound on modelled ice volume variations during the last $200 \mathrm{Ka}$, Earth and Planetary Science Letters, 184, 623-633. 
Elliot, M., Labeyrie, L., Bond, G., Cortijo, E., Turon, J.-L., Tisnerat, N. and J.-C. Duplessy (1998), Millenial-scale iceberg discharges in the Irminger basin during the last glacial period: Relationship with the Heinrich events and environmental settings, Paleoceanography, 13, 433-446.

Elliot, M., Labeyrie, L., Dokken, T., and S. Manthe (2001), Coherent patterns of ice-rafted debris deposits in the Nordic regions during the last glacial (10-60 Ka), Earth and Planetary Science Letters, 194, 151-163.

Evans, D. J. A., Clark, C. D., and W. A. Mitchell (2005), The last British Ice Sheet: a review of the evidence utilised in the compilation of the Glacial Map of Britain, Earth-Science Reviews, 70, 253-312.

Eynaud, F. (1999), Kystes de Dinoflagellés et Evolution paléoclimatique et paléohydrologique de l'Atlantique Nord au cours du Dernier Cycle Climatique du Quaternaire, PhD thesis, 291 pp. University of Bordeaux 1.

Gallup, C. D., Cheng, H., Taylor, F. W., and R. L. Edwards (2002), Direct determination of the timing of sea level change during termination II, Science, 295, 310-313.

Ganopolski, A. and S. Rahmstorf (2001), Rapid changes of glacial climate simulated in a coupled climate model, Nature, 409, 153-158.

Grousset, F., Pujol., C., Labeyrie, L., Auffret, G. A., and A. Boelaert (2000), Were the North Atlantic Heinrich events triggered by the behaviour of the European ice sheet? Geology, 28, 123-126.

Gibbard, P. L. (1988), The history of the great northwest European rivers during the past three million years, Phil. Trans. R. Soc. Lond, B318, 559-602.

Gibbard, P. L., and J. P. Lautridou (2003), The Quaternary history of the English Channel: an introduction, Journal of Quaternary Science, 18, 195-199. 
Hall, I.R., and I.N. McCave (1998a), Late glacial to recent accumulation fluxes of sediments at the shelf edge and slope of N.W. Europe, $48^{\circ}-50^{\circ} \mathrm{N}$, Geological Society of London Special Publication, 129, 339-350.

Hall, I.R., and I.N. McCave (1998b), Glacial-interglacial switching of organic carbon sources supplying the slope of N.W. Europe, $48^{\circ}-50^{\circ} \mathrm{N}$, Progress in Oceanography, 42, 37-60.

Hall, I. R., S. B. Moran, R. Zahn, P. C., Knutz, C.-C. Shen, and R. L. Edwards (2006), Accelerated drawdown of meridional overturning in the late-glacial Atlantic triggered by transient pre-H event freshwater perturbation, Geophys. Res. Lett., 33, L16616, doi:10.1029/2006GL026239.

Heinrich, H. (1988), Origin and Consequences of Cyclic Ice Rafting in the Northeast Atlantic Ocean during the Past 130,000 Year, Quaternary Research, 29, 142-152.

Hemming, S. R. (2004), Heinrich events: Massive late Pleistocene detritus layers of the North Atlantic and their global climate imprint, Reviews of Geophysics, 42, RG1005 1-43.

Hesse, R., and S. Khodabakhsh (1998), Depositional facies of late Pleistocene Heinrich events in the Labrador Sea, Geology, 26, 103-106.

Hiemstra, J. F., Evans, D. J. A., Scourse, J. D., McCarroll, D., Furze, M. F. A., and E. Rhodes (2006), New evidence for a grounded Irish Sea glaciation of the Isles of Scilly, UK, Quaternary Science Reviews, 25, 299-309.

Hulbe, C. L., MacAyeal, D. R., Denton, G. H., Kleman, J., and T. V. Lowell (2004), Catastrophic ice shelf breakup as the source of Heinrich event icebergs, Paleoceanography, 19, PA1004, doi:10.1029/2003PA000890.

Imbrie, J., Hays, J. D., Martinson, D. G., McIntyre, A., Mix, A. C., Morley, J. J., Pisias, N. G., Prell, W. L. and N. J. Shackleton, (1984), The orbital theory of Pleistocene climate: support from a revised chronology of the marine d180 record, in Milankovitch and 
Climate, Part 1, edited by A. L. Berger, J. Imbrie, J. Hays, G. Kukla and B. Saltzman,, pp. 269-305, Riedel, Hingham, MA.

Imbrie, J., McIntyre, A. and A. Mix (1989), Oceanic response to orbital forcing in the late Quaternary: observational and experimental strategies, In Climate and Geosciences, edited by Berger, A. L., Schneider, S. H., and J. C. Duplessy, pp. 121-164, Kluwer Academic Publ..

Imbrie, J., Berger, A., Boyle, E. A., Clemens, S. C., Duffy, A., Howard, W. R., Kukla, G., Kutzbach, J., Martinson, D. G., McIntyre, A., Mix, A. C., Molfino, B., Morley, J. J., Peterson, L. C., Pisias, N. G., Prell, W. L., Raymo, M. E., Shackleton, N. J., and J. R. Toggweiler (1993), On the structure and origin of major glaciation cycles .2. The 100,000 year cycle, Paleoceanography, 8, 699-735.

Johnson, R. G. (1997), Ice age initiation by an ocean-atmospheric circulation change in the Labrador Sea, Earth and Planetary Science Letters, 148, 367-379.

Kaiser, J. Caractérisation palynologique des flux terrigènes Manche-Golfe de Gascogne au cours du Dernier Maximum Glaciaire et du réchauffement holocène. Maitrise des Sciences de l'Environnement. Université Bordeaux 1. 30p

Khodri, M., Leclainche, Y., Ramstein, G., Braconnot, P., Marti, O., and E. Cortijo (2001), Simulating the amplification of orbital forcing by ocean feedbacks in the last glaciation, Nature, 410, 570 - 574.

Knight, J., and A. M. McCabe (1997), Identification and significance of ice-flow-transverse subglacial ridges (Rogen moraines) in northern central Ireland, Journal of Quaternary Science, 12, 519-524.

Knutz, P. C., Austin, W. E. N., and E. J. W. Jones (2001), Millennial-scale depositional cycles related to British ice sheet variability and North Atlantic paleocirculation since 45 Ka B.P., Barra Fan, U.K. margin, Paleoceanography, 16, 53-64. 
Knutz, P. C., R. Zahn, and I. R. Hall (2007), Centennial-scale variability of the British Ice Sheet: Implications for climate forcing and Atlantic meridional overturning circulation during the last deglaciation, Paleoceanography, 22, PA1207, doi:10.1029/2006PA001298.

Lambeck, K. (1995), Late Devensian and Holocene shorelines of the British Isles and North Sea from models of glacio-hydro-isostatic rebound, Journal of the Geological Society, 152, 437-448.

Larsonneur, C., Auffret, J.P., and A.J. Smith (1982), Carte des paleo-vallées et des bancs de la Manche orientale, BRGM 1/500 000eme.

Lea, D. W., Martin, P. A., Pak, D. K. and H. J. Spero (2002), Reconstructing a 350 ky history of sea level using planktonic Mg/Ca and oxygen isotope records from a Cocos Ridge core, Quaternary Science Reviews, 21, 283-293.

Lekens, W. A. H., Sejrup, H. P., Haflidason, H., Petersen, G. O., Hjelstuen, B., and G. Knorr (2005), Laminated sediments preceding Heinrich event 1 in the Northern North Sea and Southern Norwegian Sea: Origin, processes and regional linkage, Marine Geology, 216, 27-50.

Lericolais, G. (1997). Evolution Plio-Quaternaire du Fleuve Manche : Stratigraphie et Géomorphologie d'une Plateforme Continentale en Régime Périglaciaire, PhD thesis, 265 pp., University of Bordeaux 1.

Lericolais, G., Auffret, J.-P., and Bourillet, J.-F. (2003), The Quaternary Channel River : seismic stratigraphy of its palaeo-valleys and deeps, Journal of Quaternary Science, 18, no. 3-4, p. 245-260.

Martinson, D. G., Pisias, N. G., Hays, J. D., Imbrie, J., Moore, Jr. T. C,. and N. J. Shackleton (1987), Age dating and the orbital theory of the ice ages: Development of a high-resolution 0 to 300,000-year chronostratigraphy, Quaternary Research, 27, 1-29. 
Mangerud, J., Jansen, E. and J. Y., Landvik (1996), Late cenozoic history of the Scandinavian and barents sea ice sheets, Global \& Planetary change, 12, 11-26.

McCabe, M., Knight, J., and S. McCarron,( 1998), Evidence for Heinrich event 1 in the British Isles, Journal of Quaternary Science, 13, 549-568.

McCabe, A. M., and P.U. Clark (1998), Ice sheet variability around the North Atlantic Ocean during the last deglaciation, Nature, 392, 373-377.

McCabe, A. M., and P.U. Clark (2003), Deglacial chronology from county Donegal, Ireland: Implications for deglaciation of the British-Irish ice sheet, Journal of the Geological Society, 160, 847-855.

McCabe, A. M., Clark, P. U., and J. Clark (2005), AMS 14C dating of deglacial events in the Irish Sea Basin and other sectors of the British-Irish ice sheet, Quaternary Science Reviews, 24, 1673-1690.

McCartney, M. S., and C. Mauritzen (2001), On the origin of the warm inflow to the Nordic Seas, Progress in Oceanography, 51, 125-214.

McManus, J. F., Kelgwin, L., Francois, R., Drown-Leger, S., and J.-M. Gherardl (2004), Collapse and rapid resumption of Atlantic meridional circulation linked to deglacial climate changes, Nature, 428, 834-837.

Migeon, S., Weber, O., Faugeres, J.C., and J. Saint-Paul (1999), SCOPIX: A new imaging system for core analysis, Geo-Marine Letters, 18, 251-255.

Mix, A. E., Bard, E., and R. Schneider (2001), Environmental processes of the ice age: land, ocean, glaciers (EPILOG), Quaternary Science Reviews, 20, 627-657.

Mojtahid, M., Eynaud, F., Zaragosi, S., Scourse, J., Bourillet, J.-F., and T. Garlan (2005), Palaeoclimatology and palaeohydrography of the glacial stages on Celtic and Armorican margins over the last 360000 yrs, Marine Geology, 224, 57-82. 
Paillard, D., Labeyrie, L., and P. Yiou (1993), Macintosh program performs time-series analysis. EOS Trans. AGU, 77, 379.

Paillard, D. (2001), Glacial hiccups, Nature, 409, 147-148.

Peck, V. L., Hall, I. R., Zahn, R., Elderfield, H., Grousset, F., Hemming, S. R., and J. D. Scourse (2006), High resolution evidence for linkages between NW European ice sheet instability and Atlantic Meridional Overturning Circulation, Earth and Planetary Science Letters, 243, 476-488.

Petoukhov, V., Claussen, M., Berger, A., Crucifix, M., Eby, M., Eliseev, A. V., Fichefet, T., Ganopolski, A., Goosse, H., Kamenkovich, I., Mokhov, I. I., Montoya, M., Mysak, L. A., Sokolov, A., Stone, P., Wang, Z. and A. J. Weaver (2005), EMIC Intercomparison Project EMIP-CO2: Comparative analysis of EMIC simulations of climate, and of equilibrium and transient responses to atmospheric CO2 doubling, Climate Dynamics, 25, 363-385.

Piotrowski, A. M., Goldstein, S. L., Hemming, S. R., and R. G. Fairbanks (2004), Intensification and variability of ocean thermohaline circulation through the last deglaciation, Earth and Planetary Science Letters, 225, 205-220.

Piotrowski, A. M., Goldstein, S. L., Hemming, S. R., and R. G. Fairbanks (2005), Temporal relationship of carbon cycling and ocean circulation at glacial boundaries, Science, 307, 1933-1938.

Rahmstorf, S. (1999), Shifting seas in the greenhouse?, Nature, 399, 523-524.

Raymo, M.E. (1997), The timing of major climate terminations, Paleoceanography, 12, 577585.

Raymo, M. E., Oppo, D. W., Flower, B. P., Hodell, D. A., McManus, J. F., Venz, K. A., Kleiven, K. F., and K. McIntyre (2004), Stability of North Atlantic water masses in face of pronounced climate variability during the Pleistocene, Paleoceanography, 19, PA2008 113. 
Richter, T. O., Lassen, S., van Weering, Tj.-C.-E., and H. De Haas (2001), Magnetic susceptibility patterns and provenance of ice-rafted material at Feni Drift, Rochall Trough: implications for the history of the British-Irish ice sheet, Marine Geology, 173, 37-54.

Roche, D., Paillard, D., and E. Cortijo (2004), Constraints on the duration and freshwater release of Heinrich event 4 through isotope modelling, Nature, 432, 379-382.

Sanchez Goni, M. F., Eynaud, F., Turon, J. L. and N. J. Shackleton (1999), High resolution palynological record off the Iberian margin: direct land-sea correlation for the Last Interglacial complex, Earth and Planetary Science Letters, 171, 123-137.

Schönfeld, J., and R. Zahn (2000), Late Glacial to Holocene history of the Mediterranean outflow. Evidence from benthic foraminiferal assemblages and stable isotopes at the Portuguese margin, Palaeogeography, Palaeoclimatology, Palaeoecology, 159, 85-111.

Scourse, J. D. (1997), Transport of the Stonehenge bluestones: testing the glacial hypothesis, Proceedings of the British Academy, 92, 271-314.

Scourse, J. D., Hall, I. R., Mc Cave, I.-N., Young, J.-R., and C. Sugdon (2000), The origin of Heinrich layers: evidence from $\mathrm{H} 2$ for European precursor events, Earth and Planetary Science Letters, 182, 187-195.

Scourse, J.D., and M.F.A. Furze (2001), A critical review of the glaciomarine model for Irish Sea deglaciation: evidence from southern Britain, the Celtic shelf and adjacent continental slope, Journal of Quaternary Science, 16, 419-434.

Seidenkrantz, M. S., Bornmalm, L., Johnsen, S. J., Knudsen, K. L., Kuijpers, A., Lauritzen, S.-E., Leroy, S. A. G., Mergeai, I., Schweger, C. and B. Van Vliet-Lanoë (1996), TwoStep deglaciation at the oxygen isotope stage 6/5e transition: the Zeifen-Kattegat climate oscillation, Quaternary Science Review, 15, 63-75.

Seidov, D., and B. J. Haupt (2003), On sensitivity of ocean circulation to sea surface salinity, Global and Planetary Change, 36, 99-116. 
Shackleton, N.J., Imbrie, J., and N.G. Pisias (1988), The evolution of oceanic oxygen-isotope variability in the North Atlantic over the past three million years, Philos. Trans. $R$. Soc. Lond., B 318, 679.

Shackleton, N. J. (2000), The 100,000-Year Ice-Age Cycle Identified and Found to Lag Temperature, Carbon Dioxide, and Orbital Eccentricity, Science, 289, 1897-1902.

Shennan, I., Lambeck, K., Horton, B., Innes J., Lloyd J., McArthur J., Purcell T., and M. Rutherford (2000), Late Devensian and Holocene records of relative sea-level changes in northwest Scotland and their implications for glacio-hydro-isostatic modelling, Quaternary Science Reviews, 19, 1103-1135.

Shennan, I., Peltier, W. R., Drummond, R., and B. Horton (2002), Global to local scale parameters determining relative sea-level changes and the post-glacial isostatic adjustment of Great Britain, Quaternary Science Reviews, 21, 397-408.

Siddall, M., E. J. Rohling, A. Almogi-Labin, Ch. Hemleben, D. Meischner, I. Schmelzer, and D. A. Smeed (2003), Sea-level fluctuations during the last glacial cycle, Nature, 423, 853858.

Siddall, M., T. F. Stocker, T. Blunier, R. Spahni, J. Schwander, J.-M. Barnola, and J. Chappellaz (2007), Marine Isotope Stage (MIS) 8 millennial variability stratigraphically identical to MIS 3, Paleoceanography, 22, PA1208, doi:10.1029/2006PA001345.

Schneider, R., Müller, P.-J., and R. Acheson (1999), Atlantic Alkenone sea-surface temperature records, Low versus mid latitudes and differences between hemispheres, in Reconstructing ocean history: A window into the future, edited by F. Abrantes and A. C. Mix, pp 33-56, Plenum, New-York.

Stocker, T. F., and A. Schmittner (1997), Influence of CO2 emission rates on the stability of the thermohaline circulation, Nature, 388, 862-865. 
Stokes, C. R., and C. D. Clark (2001), Palaeo-ice streams, Quaternary Science Reviews, 20, $1437-1457$.

Thouveny, N., Moreno, E., Delanghe, D., Candon, L., Lancelot, Y. and N. J. Shackleton (2000), Rock magnetic detection of distal ice-rafted debries: clue for the identification of Heinrich layers on the Portuguese margin, Earth and Planetary Science Letters, 180, 6175.

Tian, J., Brown, T. A., and F. S. Hu (2005), Comparison of varve and ${ }^{14} \mathrm{C}$ chronologies from Steel Lake, Minnesota, USA, The Holocene, 15, 510-517.

Uehara, K., Scourse, J.D., Horsburgh, K.J., Lambeck, K., A. Purcell (In press), Tidal evolution of the northwest European shelf seas from the Last Glacial Maximum to the present, Journal of Geophysical Research, 111, doi:10.1029/2006JC003531

Van Aken, H. M. (2000), The hydrography of the mid-latitude Northeast Atlantic Ocean II: The intermediate water masses, Deep-Sea Research Part I, 47, 789-824.

Voelker, A. H. L., Lebreiro, S. M., Schoenfeld, J., Cacho, I., Erlenkeuser, H., and F. Abrantes (2006), Mediterranean outflow strengthening during northern hemisphere coolings: A salt source for the glacial Atlantic?, Earth and Planetary Science Letters, 245, 39-55.

Waelbroeck, C., Duplessy, J.-C., Michel, E., Labeyrie, L., Paillard, D., and J. Duprat (2001), The timing of the last deglaciation in North Atlantic climate records, Nature, 412, 724-727.

Waelbroeck, C., Labeyrie, L., Michel, E., Duplessy, J. C., McManus, J. F., Lambeck, K., Balbon, E., and M. Labracherie (2002), Sea-level and deep water temperature changes derived from benthic foraminifera isotopic records, Quaternary Science Reviews, 21, 295305.

Wood, R. A., Keen, A. B., Mitchell, J. F. B., and J. M. Gregory (1999), Changing spatial structural the thermohaline circulation in response to atmospheric CO2 forcing in a climate model, Nature, 399, 572-575. 
Winograd, I. J., Coplen, T. B., Landwwehr, J. M., Riggs, A. C., Ludwig, K. R., Szabo, B. J., Kolesar, P. T., and K. M. Revesz (1992), Continous 500,000-Year Climate Record from vein calcite in Devils Hole, Nevada, Science, 258, 255-260.

Winograd, I. J., Landwehr, J. M., Ludwig, K. R., Coplen, T. B., and A. C. Riggs (1997), Duration and structure of the past four interglaciations, Quaternary Research, 48, 141-154.

Zaragosi, S., Auffret, G. A., Faugeres, J. C., Garlan, T., Pujol, C., and E. Cortijo (2000), Physiography and recent sediment distribution of the Celtic Deep-sea Fan, Bay of Biscay, Marine Geology, 169, 207-237.

Zaragosi, S., Eynaud, F., Pujol, C., Auffret, G. A., Turon, J. L., and T. Garlan (2001a), Initiation of European deglaciation as recorded in the northwestern Bay of Biscay slope environments (Meriadzek Terrace and Trevelyan Escarpment) : a multi-proxy approach, Earth and Planetary Science Letters, 188, 493-507.

Zaragosi S, Le Suave R, Bourillet J-F, Auffret GA, Faugères J-C, Pujol C, Garlan T (2001b), The deep-sea Armorican depositional system (Bay of Biscay), a multiple source, ramp model. Geomarine Letters, 20(4), 219-232

Zaragosi, S., Bourillet, J-F., Eynaud, F., Toucanne, S., Denhard B., Van Toer A., and V. Lanfumey (2006), The impact of the last European deglaciation on the deep-sea turbidite systems of the Celtic-Armorican margin (Bay of Biscay), Geomarine Letters, 26(6), 317329. 


\section{FIGURE CAPTION :}

821

822

Figure 1: Location of the studied cores along the Celtic margin in relation to the palaeogeography of the adjacent continent during the LGM (BIIS maximal extension, after Stokes et al., 2001); the palaeovalleys of the Manche river (after Lericolais,1997) are shown in dark blue. Bathymetric contour intervals are $50 \mathrm{~m}$ on the shelf $(0-250 \mathrm{~m}), 500 \mathrm{~m}$ on the slope (500 - $4000 \mathrm{~m}$ ) and $1000 \mathrm{~m}$ in the deep sea (4000 - $4900 \mathrm{~m}$ ).

Schematic view (after Blindheim et al., 2000; McCartney and Mauritzen, 2001) of the North Atlantic major surface currents (NAD: North Atlantic Drift, NAC: Norwegian Atlantic Current, IC: Irminger Current) and the intermediate Mediterranean Outflow Water current (MOW).

Figure 2: Age models for the last 30 ka BP of the two reference cores MD95-2002 and MD03-2692 (see al so Table 2).

Figure 3: Position of the laminated sequences (number of laminae per $\mathrm{cm}$ ) in the respective cores studied with regards to the light reflectance data $\left(\mathrm{L}^{*}\right)$. Grey bars underline the interglacial marine isotopic stages (MIS 5 to 9). The dark star localize a deep-sea coral that has been found during the sampling procedure of core MD01-2461 and dated by U-TH methods (GEOTOP, http://www.geotop.uqam.ca/).

Figure 4: X-ray imagery and microphotography of the sediment thin sections corresponding to laminae in (a) MIS 2- core MD01-2461 and (b) MIS 6-core MD03-2692. Black arrows indicate the laminae position and are proportional to the larger grain concentrations. Black stars indicate ${ }^{14} \mathrm{C}$ AMS age positions in core MD03-2692 $\left(15,100 \mathrm{yr}^{14} \mathrm{C} \mathrm{BP}\right.$ at $203 \mathrm{~cm}$ and 
844

845

846

847

848

849

850

851

852

853

854

855

856

857

858

859

860

861

862

863

864

865

866

867

868

$15,160 \mathrm{yr}^{14} \mathrm{C} \mathrm{BP}$ at $260 \mathrm{~cm}$ ). (c) Grain size diagrams showing in red X-Ray bright laminae, in black X-ray dark laminae. (c1) : MIS2 in core MD03-2692; (c2) : MIS6 in core MD01-2461.

Figure 5: Structure of Termination I (5a, 5b) and II $(5 c, 5 d, 5 e)$ with regard to the multiproxy studies conducted on the cores (No. of laminae /cm; \% Nps: relative frequencies of the polar species Neogloquadrina pachyderma s.; CLG. c.: coarse lithic grain concentrations; palynomorphs: concentration in Pediastrum sp. $/ \mathrm{cm}^{3}$, \% Estuar. d. : relative frequencies of the estuarine dinocyst species, nQ/Q : Ratio non Quat. din./Quat. din.). The same depth scale has been kept for each of the section presented here to highlight the difference in the recovery of the laminae events (grey bars). For core sections of MIS2, the limits of the Heinrich Event 1 (HE1) conform to those published by Zaragosi et al. (2001a, Figure 6) and Elliot et al. (1998, 2001). The end of the Last Glacial Maximum (LGM) period is also noted. The grey bands underline the laminae events only.

Figure 6: MIS2 BIIS MWP in cores MD95-2002 and MD03-2692. Empty losangic dots indicate the age control points. HE1 and HE2 limits after Elliot et al. (1998; 2001) after conversion with CALIB (version 5.1.0 with the MARINE04 data set, incorporating a $400 \mathrm{yr}$ correction for marine reservoir). The mid-ages of theses events (dark horizontal bars) are taken from Thouveny et al. (2000); for HE1 it conforms to those of Bond et al. (1997), Peck et al. (2006) and to the Heinrich 1 meltwater event of Hall et al. (2006); vertical bars on the left locate the major hydrographic events identified in the proximal North Atlantic Ocean: AMOC collapse (after Mc Manus et al., 2004); BMevent: British Margin negative $\delta^{18} \mathrm{O}$ event (after Knutz et al., 2007).

Losangic dots locate terrestrial events of the BIIS history. BIIS -DEG: BIIS extensive deglaciation, BIIS-MAX: maximum BIIS size, after Bowen et al. (2002); KPS: Killard Point 
869

870

871

873

874

875

stadial after McCabe et al. (2005); K-MWP: Kilkeel meltwater pulse after Clark et al. (2004). Planktonic $\delta^{18} \mathrm{O}$ measurements in MD95-2002 were carried out on G. bulloides and $N$. pachyderma,; benthic $\delta^{18} \mathrm{O}$ measurements in MD03-2692 were carried out on Uvigerina peregrina, Pullenia bulloides and Planulina wuellerstorfi.

Figure 7: MIS6 BIIS MWP in core MD03-2692 (labels: \% Nps: relative frequencies of the polar species Neogloquadrina pachyderma s.; CLG. c.: coarse lithic grain concentrations). Ages indicated on the right are those used as tie-points for the construction of the age model (correlation with SPECMAP $\delta^{18} \mathrm{O}$ benthic record, Martinson et al., 1987; The SPECMAP stack was obtained from ftp://ftp.ncdc.noaa.gov/pub/data/paleo/paleocean/specmap/). Insolation values after Berger et Loutre, 1991. The Termination 2 limits are those cited in Cannariato and Kennet, 2005. Black stars on the right localized the tie-points used to constrain the age model by a direct comparison with the SPECMAP $\delta^{18} \mathrm{O}$ curve (Martinson et al., 1987).

\section{TABLE CAPTION :}

Table 1: Details of the studied cores.

Table 2 : Radiocarbon control points used for the reference cores. $\Delta \mathrm{a}{ }^{14} \mathrm{C}$ : age uncertainty; 1 sigma values are based on the calibrated age range and indicate the margin between the mean age (CALIB5.1.0. calculations). 


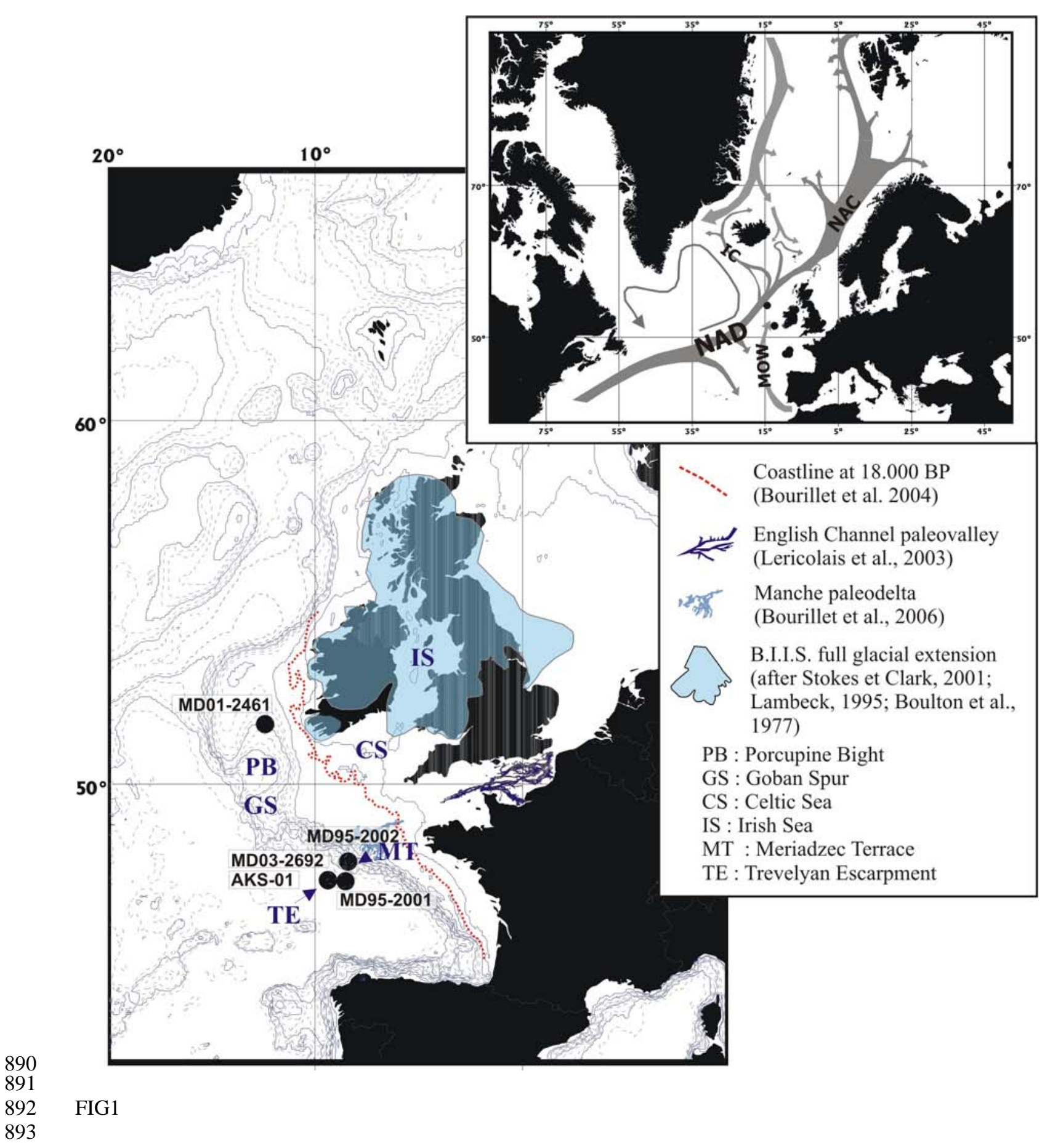



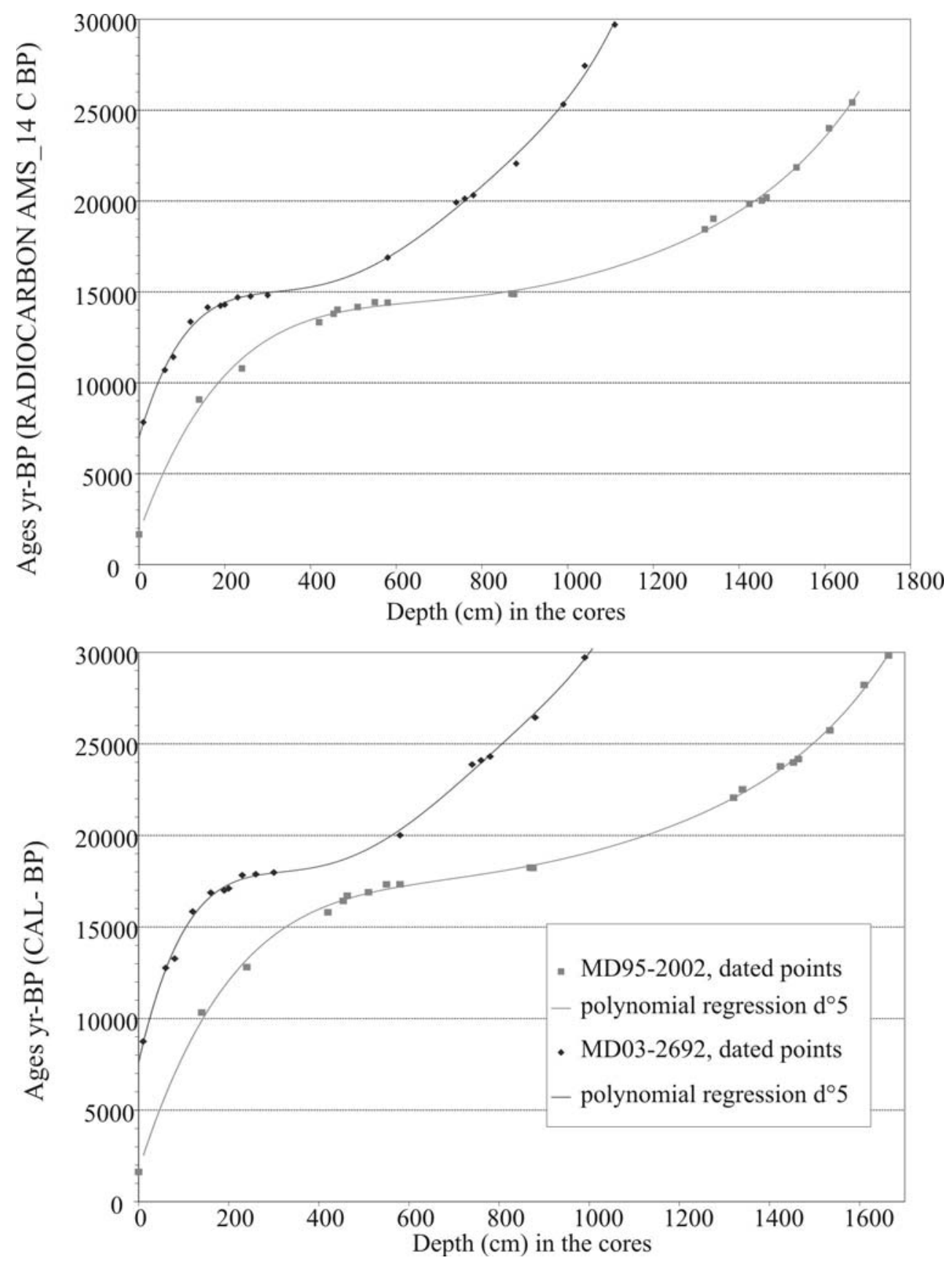


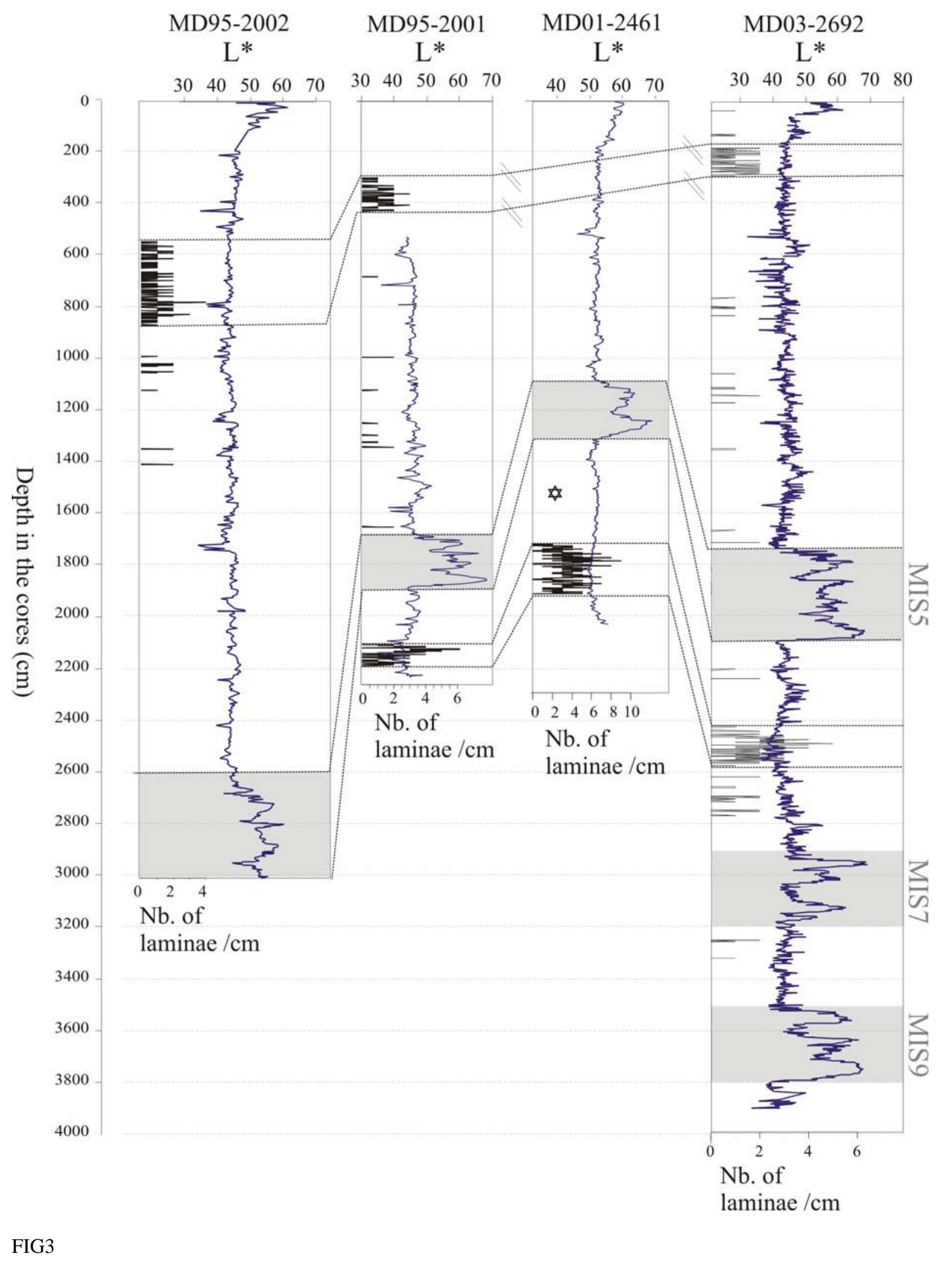




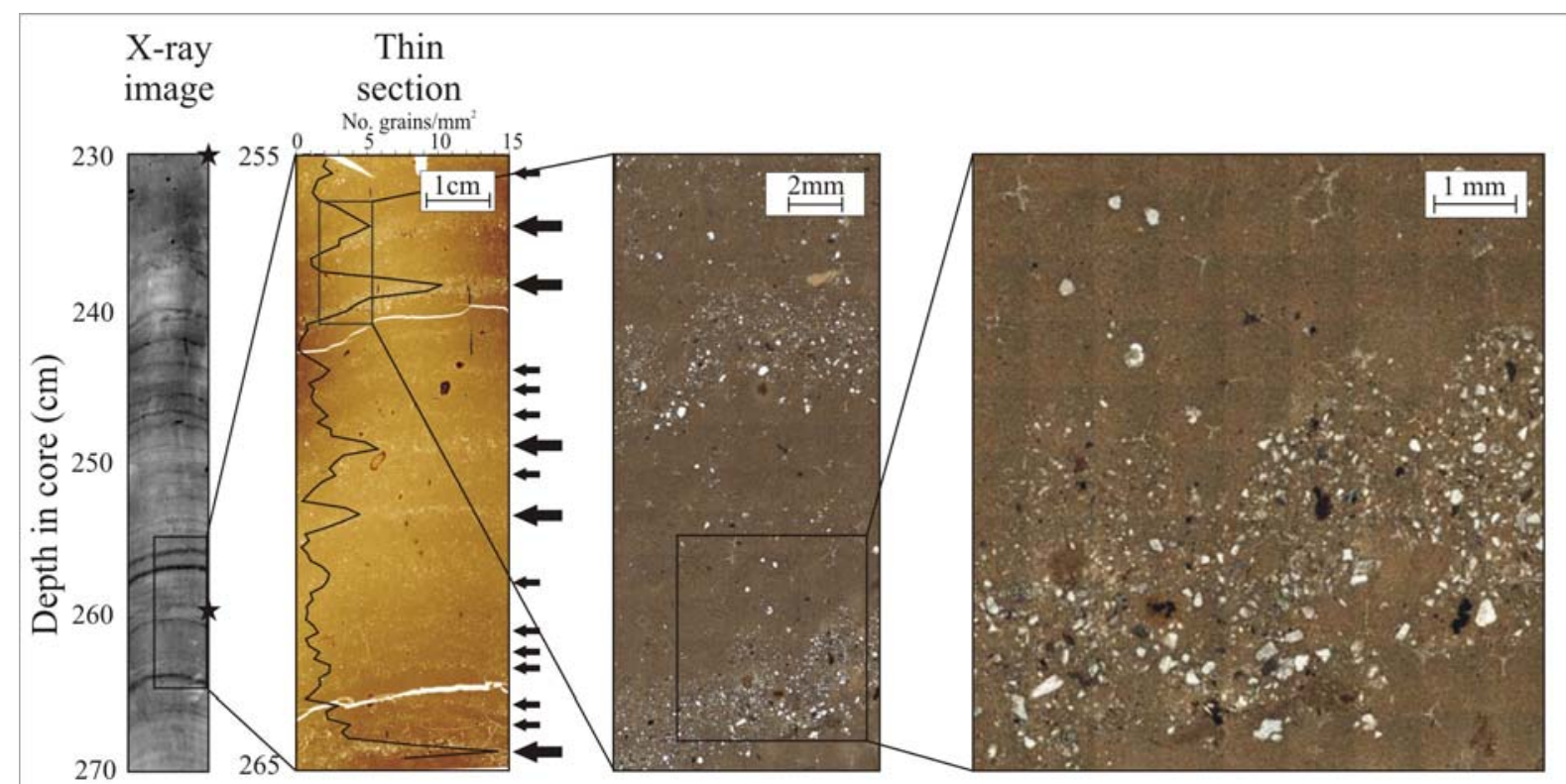

(a) MD03-2692, MIS 2

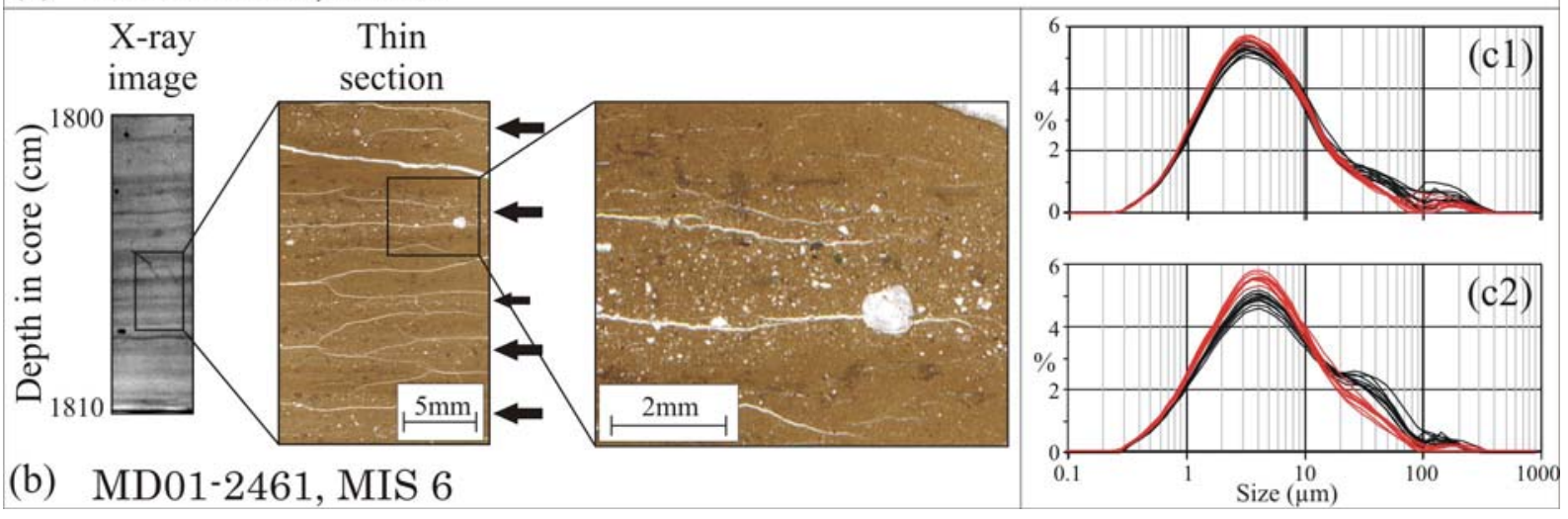

FIG4 

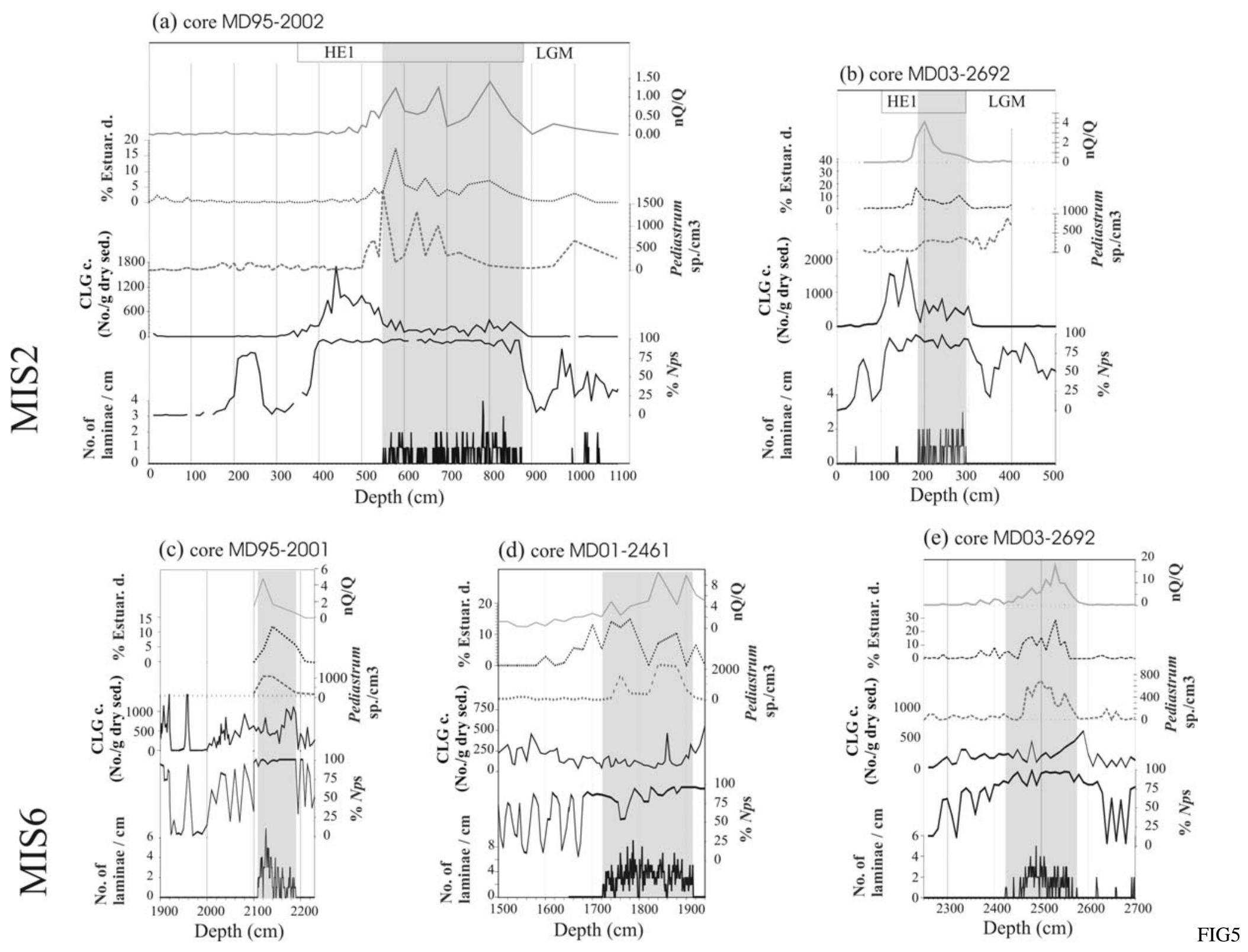

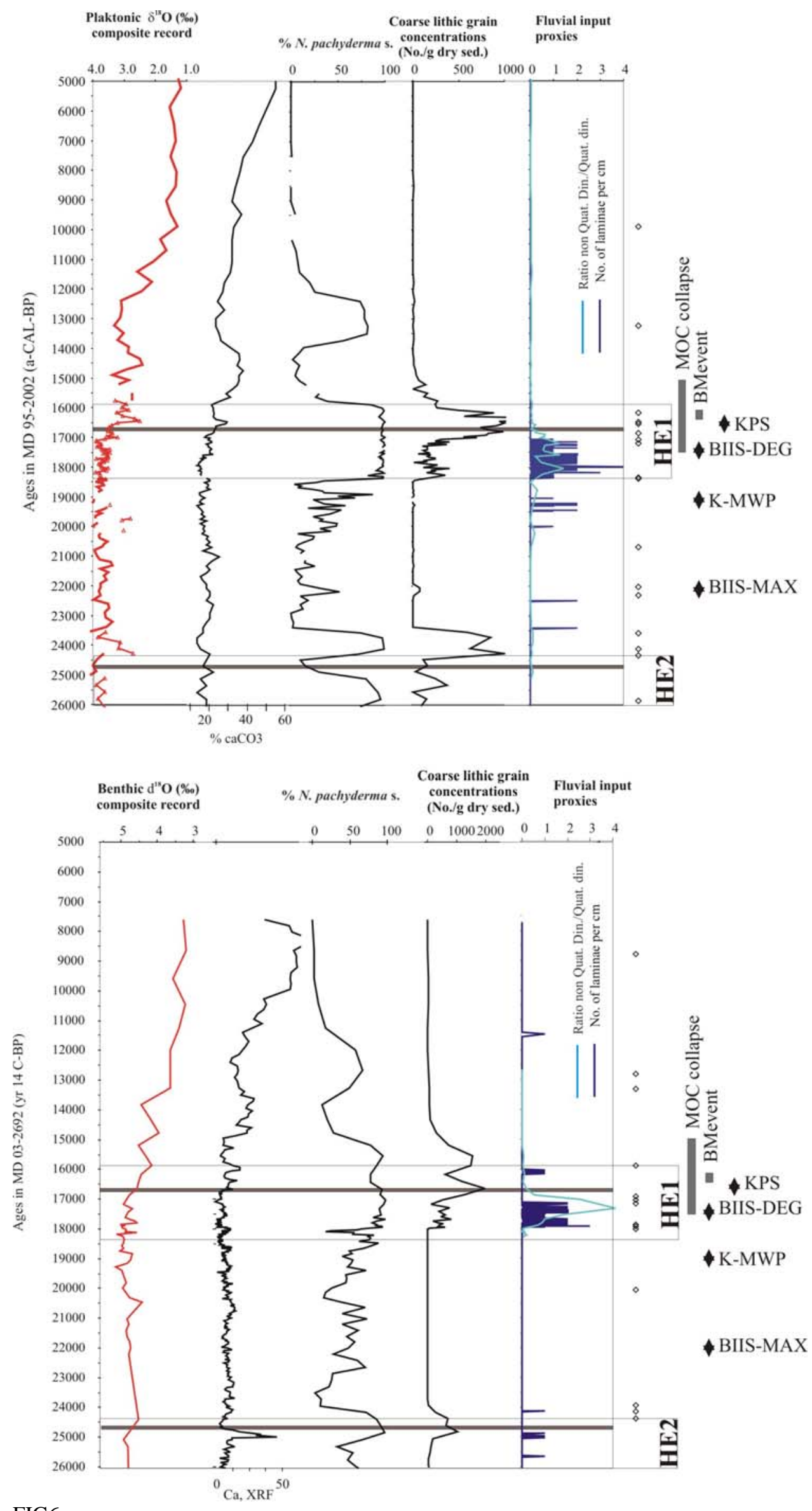


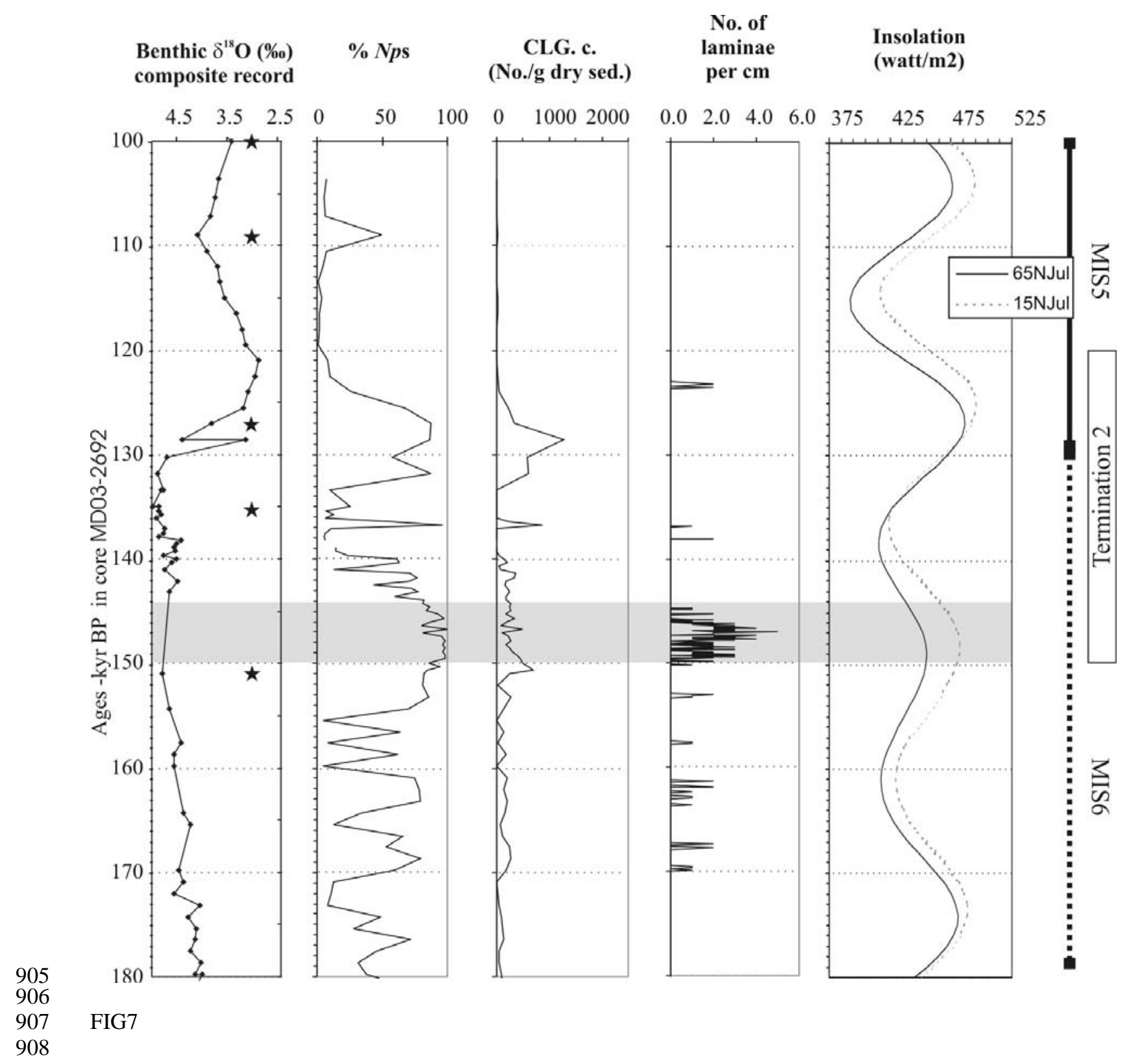




\begin{tabular}{|c|c|c|c|c|c|c|c|}
\hline Core & Latitude $\left({ }^{\circ} \mathbf{N}\right)$ & Longitude $\left({ }^{\circ} \mathbf{E}\right)$ & Waterdepth $(\mathbf{m})$ & Corelength (m) & Cruise & Year & Institute \\
\hline MD95-2001 & 46.80 & -8.67 & 3788 & 22 & IMAGES 1 & 1995 & IFRTP \\
\hline MD95-2002 & 47.45 & -8.53 & 2174 & 30 & IMAGES 1 & 1995 & IFRTP \\
\hline MD01-2461 & 51.75 & -12.55 & 1153 & 21 & GEOSCIENCES & 2001 & IFRTP \\
\hline MD03-2692 & 46.83 & -9.52 & 4060 & 39 & SEDICAR & 2003 & IFRTP \\
\hline AKS01 & 46.83 & -9.52 & 4030 & 5 & ACORES & 1996 & SHOM \\
\hline
\end{tabular}




\begin{tabular}{|c|c|c|c|c|c|c|c|c|c|}
\hline $\begin{array}{l}\text { depth } \\
\text { (cm) }\end{array}$ & $\begin{array}{l}\text { Radiocarbo } \\
\text { n age (yr) }\end{array}$ & $\begin{array}{l}\Delta \mathrm{a} \\
14 \mathrm{C}\end{array}$ & $\begin{array}{l}\text { Radiocarbon } \\
\text { age }(\mathrm{yr})- \\
400 \mathrm{yr} \\
\text { reservoir age }\end{array}$ & $\begin{array}{l}\text { calendar } \\
\text { age (yr } \\
\text { BP) }\end{array}$ & 1 sigma & Lab-number & AMS lab & Species & Cited in \\
\hline \multicolumn{10}{|l|}{$\begin{array}{l}\text { MD95- } \\
2002\end{array}$} \\
\hline 0 & 2060 & 70 & 1660 & 1624 & 87 & 99360 & LSCE & G. bulloides & Zaragosi et al., 2001a Auffret et al., 2002 \\
\hline 140 & 9480 & 90 & 9080 & 10329 & 101 & 99361 & LSCE & G. bulloides & Zaragosi et al., 2001a Auffret et al., 2002 \\
\hline 240 & 11190 & 100 & 10790 & 12809 & 70 & 99362 & LSCE & N. pachyderma & Zaragosi et al., 2001a Auffret et al., 2002 \\
\hline 420 & 13730 & 130 & 13330 & 15798 & 248 & 99363 & LSCE & N. pachyderma & Zaragosi et al., 2001a Auffret et al., 2002 \\
\hline 454 & 14200 & 110 & 13800 & 16426 & 232 & 99364 & LSCE & N. pachyderma & Zaragosi et al., 2001a Auffret et al., 2002 \\
\hline 463 & 14420 & 120 & 14020 & 16709 & 232 & 99365 & LSCE & N. pachyderma & Zaragosi et al., 2001a Auffret et al., 2002 \\
\hline 510 & 14570 & 130 & 14170 & 16897 & 269 & 99366 & LSCE & N. pachyderma & Zaragosi et al., 2001a Auffret et al., 2002 \\
\hline 550 & 14830 & 70 & 14430 & 17327 & 232 & 003242 & ARTEMIS & N. pachyderma & Zaragosi et al., 2006 \\
\hline 580 & 14810 & 200 & 14410 & 17332 & 376 & Beta-141702 & b-analytic & N. pachyderma & Zaragosi et al., 2001 Auffret et al., 2002 \\
\hline 869 & 15300 & 70 & 14900 & 18241 & 238 & 003243 & ARTEMIS & N. pachyderma & Zaragosi et al., 2006 \\
\hline 875 & 15280 & 160 & 14880 & 18224 & 290 & 003244 & ARTEMIS & N. pachyderma & Zaragosi et al., 2006 \\
\hline 1320 & 18850 & 90 & 18450 & 22062 & 139 & 003245 & ARTEMIS & G. bulloides & Zaragosi et al., 2006 \\
\hline 1340 & 19430 & 100 & 19030 & 22514 & 106 & 003246 & ARTEMIS & G. bulloides & Zaragosi et al., 2006 \\
\hline 1390 & 20620 & 80 & 20220 & 24690 & 173 & 003247 & ARTEMIS & G. bulloides & Zaragosi et al., 2006 \\
\hline 1424 & 20240 & 60 & 19840 & 23777 & 127 & Beta-123696 & b-analytic & N. pachyderma & Zaragosi et al., 2001a Auffret et al., 2002 \\
\hline 1453 & 20430 & 80 & 20030 & 23984 & 135 & Beta-123698 & b-analytic & N. pachyderma & Zaragosi et al., 2001a Auffret et al., 2002 \\
\hline 1464 & 20600 & 80 & 20200 & 24174 & 137 & Beta-123699 & b-analytic & N. pachyderma & Zaragosi et al., 2001a Auffret et al., 2002 \\
\hline 1534 & 22250 & 70 & 21850 & 25734 & & Beta-123697 & b-analytic & N. pachyderma & Auffret et al., 2002 \\
\hline 1610 & 24410 & 250 & 24010 & 28222 & & Beta-99367 & b-analytic & N. pachyderma & Auffret et al., 2002 \\
\hline 1664 & 25820 & 230 & 25420 & 29830 & & Beta-99368 & b-analytic & N. pachyderma & Auffret et al., 2002 \\
\hline \multicolumn{10}{|l|}{$\begin{array}{l}\text { MD03- } \\
2692\end{array}$} \\
\hline 10 & 8230 & 60 & 7830 & 8747 & 112 & 001895 & ARTEMIS & G. bulloides & this work \\
\hline 60 & 11100 & 60 & 10700 & 12764 & 52 & 001896 & ARTEMIS & \multicolumn{2}{|c|}{ N. pachyderma sin. this work } \\
\hline 80 & 11820 & 60 & 11420 & 13272 & 54 & 001897 & ARTEMIS & G.bulloides & this work \\
\hline 120 & 13760 & 70 & 13360 & 15843 & 196 & 001898 & ARTEMIS & \multicolumn{2}{|c|}{ N. pachyderma sin. this work } \\
\hline 160 & 14550 & 70 & 14150 & 16874 & 209 & 001899 & ARTEMIS & \multicolumn{2}{|c|}{ N. pachyderma sin. this work } \\
\hline 190 & 14640 & 70 & 14240 & 16998 & 222 & 001900 & ARTEMIS & \multicolumn{2}{|c|}{ N. pachyderma sin. this work } \\
\hline 200 & 14700 & 70 & 14300 & 17108 & 227 & 001901 & ARTEMIS & \multicolumn{2}{|c|}{ N. pachyderma sin. this work } \\
\hline 230 & 15100 & 80 & 14700 & 17828 & 174 & 001902 & ARTEMIS & \multicolumn{2}{|c|}{ N. pachyderma sin. this work } \\
\hline 260 & 15160 & 80 & 14760 & 17883 & 165 & 001903 & ARTEMIS & \multicolumn{2}{|c|}{ N. pachyderma sin. this work } \\
\hline 300 & 15220 & 80 & 14820 & 17976 & 166 & 001904 & ARTEMIS & \multicolumn{2}{|c|}{ N. pachyderma sin. this work } \\
\hline 580 & 17290 & 90 & 16890 & 20010 & 103 & 001905 & ARTEMIS & G. bulloides & this work \\
\hline 740 & 20320 & 130 & 19920 & 23871 & 185 & 001906 & ARTEMIS & G. bulloides & this work \\
\hline 760 & 20530 & 130 & 20130 & 24095 & 177 & 001907 & ARTEMIS & G. bulloides & this work \\
\hline 780 & 20720 & 140 & 20320 & 24308 & 179 & 001908 & ARTEMIS & \multicolumn{2}{|c|}{ N. pachyderma sin. this work } \\
\hline 880 & 22460 & 160 & 22060 & 26440 & & 001909 & ARTEMIS & \multicolumn{2}{|c|}{ N. pachyderma sin. this work } \\
\hline \multicolumn{10}{|l|}{912} \\
\hline $\begin{array}{l}913 \\
914\end{array}$ & able 2 & & & & & & & & \\
\hline
\end{tabular}

